\title{
The Archaeology of the Archaic Periods in East Texas
}

Timothy K. Perttula

Heritage Research Center, Stephen F. Austin State University

Follow this and additional works at: https://scholarworks.sfasu.edu/ita

Part of the American Material Culture Commons, Archaeological Anthropology Commons, Environmental Studies Commons, Other American Studies Commons, Other Arts and Humanities Commons, Other History of Art, Architecture, and Archaeology Commons, and the United States History Commons

Tell us how this article helped you.

This Article is brought to you for free and open access by the Center for Regional Heritage Research at SFA ScholarWorks. It has been accepted for inclusion in Index of Texas Archaeology: Open Access Gray Literature from the Lone Star State by an authorized editor of SFA ScholarWorks. For more information, please contact cdsscholarworks@sfasu.edu. 


\section{The Archaeology of the Archaic Periods in East Texas}

Creative Commons License

(c) (i) (8)

This work is licensed under a Creative Commons Attribution-NonCommercial 4.0 International License 


\title{
The Archaeology of the Archaic Periods in East Texas
}

\author{
Timothy K. Perttula
}

\section{INTRODUCTION}

The archaeology of the Archaic periods-Early, ca. 10,000-8000 years B.P., Middle, ca. 8000-5000 years B.P., and Late, ca. 5000-2500 years B.P.- -in East Texas is not well understood in broad terms, although valuable information on the archaeological character of the Archaic peoples in the region has been gained over the years from the detailed investigation of a few specific sites (Figure 1). New knowledge concerning the archaeology of the Archaic periods in East Texas is slow in coming, due in part to the kinds of Archaic sites that have been identified by archaeologists during survey investigations and/or recommended by archeologists, state agencies, and federal agencies for further work; a general inability to identify contextually intact buried sites in the valleys of East Texas rivers and creeks; and the lack of development of a chronology based on well-controlled absolute dating of features or buried occupation zones in single component or multi-component stratified sites.

This article summarizes what is currently known about Archaic peoples and groups over this lengthy period of time in the East Texas region, including the kinds of sites that have been investigated, their known or estimated chronological age, and their associated material culture remains; it does not attempt to rectify the limitations of the known Archaic archaeological record, but rather judiciously presents archaeological findings from selected sites in East Texas, as well as in northwestern Louisiana. Some broad themes of the Archaic in the Eastern Woodlands and Southeastern U.S. (see Anderson et al. 2007; Anderson and Sassaman 2012; Emerson et al. 2009; Sassaman 2010) also come under consideration, particularly the lack of complexity and the notable apparent absence of evidence of Archaic ritual beliefs (see Claassen 2015) seen in the East Texas archaeological record compared to neighboring regions.

\section{Modern Setting and Holocene Environmental Change}

Within the broad region of the state that encompasses East Texas, there are three main biotic communities or physiographic zones: the Oak Woods and Prairies or Post Oak Savanna, the Blackland Prairie, and the Pineywoods (Diggs et al. 2006). The Pineywoods cover large parts of East Texas (Figure 2), have mediumtall to tall broadleaf deciduous forests in more mesic habitats, and shortleaf and loblolly pines are common on upland fine sandy loam soils with adequate moisture. Small areas of tall grass prairie may be present throughout the region (e.g., Jordan 1981:Figure 4.1), and this may be particularly the case in more xeric sandy lands. Bottomland communities along the major river and creek drainages contain a diverse hardwood and swamp forest (including cypress, tupelo, and sweet gum), with natural levees and alluvial terraces, point bar deposits, old stream channels, oxbow lakes, and backwater swamps. A less diverse bottomland hardwood community is present along the smaller creeks and their tributaries. The Red, Sulphur, Big Cypress, Sabine, Neches, Angelina, and Trinity rivers flow east and southeast through the Pineywoods (see Figure 1), but only the Angelina River and its tributaries originate in the Pineywoods.

The Post Oak Savanna is a narrow $(60-80 \mathrm{~km})$ southwest-northeast trending woodland belt that marks an ecotone or natural transition zone between the more xeric Blackland Prairie to the west and the more mesic Pineywoods to the east (see Figure 2). The Red, Sulphur, Big Cypress, Sabine, Neches, and Trinity rivers cut through the Post Oak Savanna, with the Big Cypress and Neches stream basins originating in this physiographic zone. The woodlands in the Post Oak Savanna consist of medium-tall to tall broadleaf deciduous forests, including several species of oak, as well as hickory and pecan. 


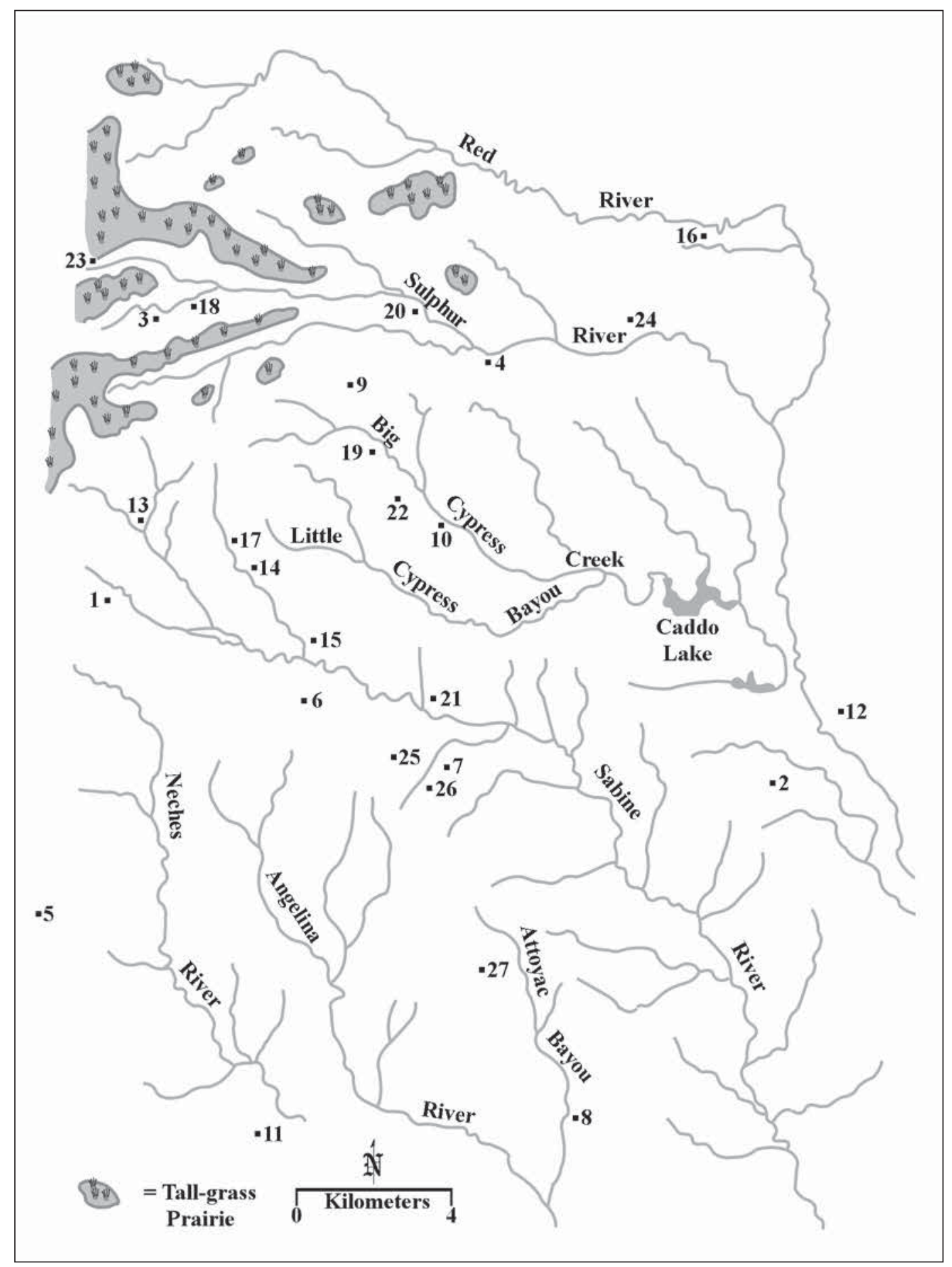

Figure 1. East Texas and Archaic sites/components mentioned in the text: 1, Yarbrough; 2, John Pearce; 3, Finley Fan; 4, Unionville; 5, 41AN115; 6, Browning phase sites; 7, Herman Ballew; 8, Wolfshead; 9, Tankersley Creek; 10, Jake Martin; 11, Hickory Creek \#2; 12, Conly; 13, Howle; 14, 41WD114; 15, 41UR77; 16, 41BW422; 17, 41WD185; 18, Hurricane Hill; 19, Pilgrim's Pride and Polk Estates; 20, Cheatwood locality (see Cheatwood 1988); 21, Grace Creek \#1/2; 22, Kitchen Branch; 23; 41FN66; 24, Weaver Creek; 25, 41RK468; 26, Oak Hill Village; 27, 41NA285 and 41NA290. Figure drawn by Lance Trask. 


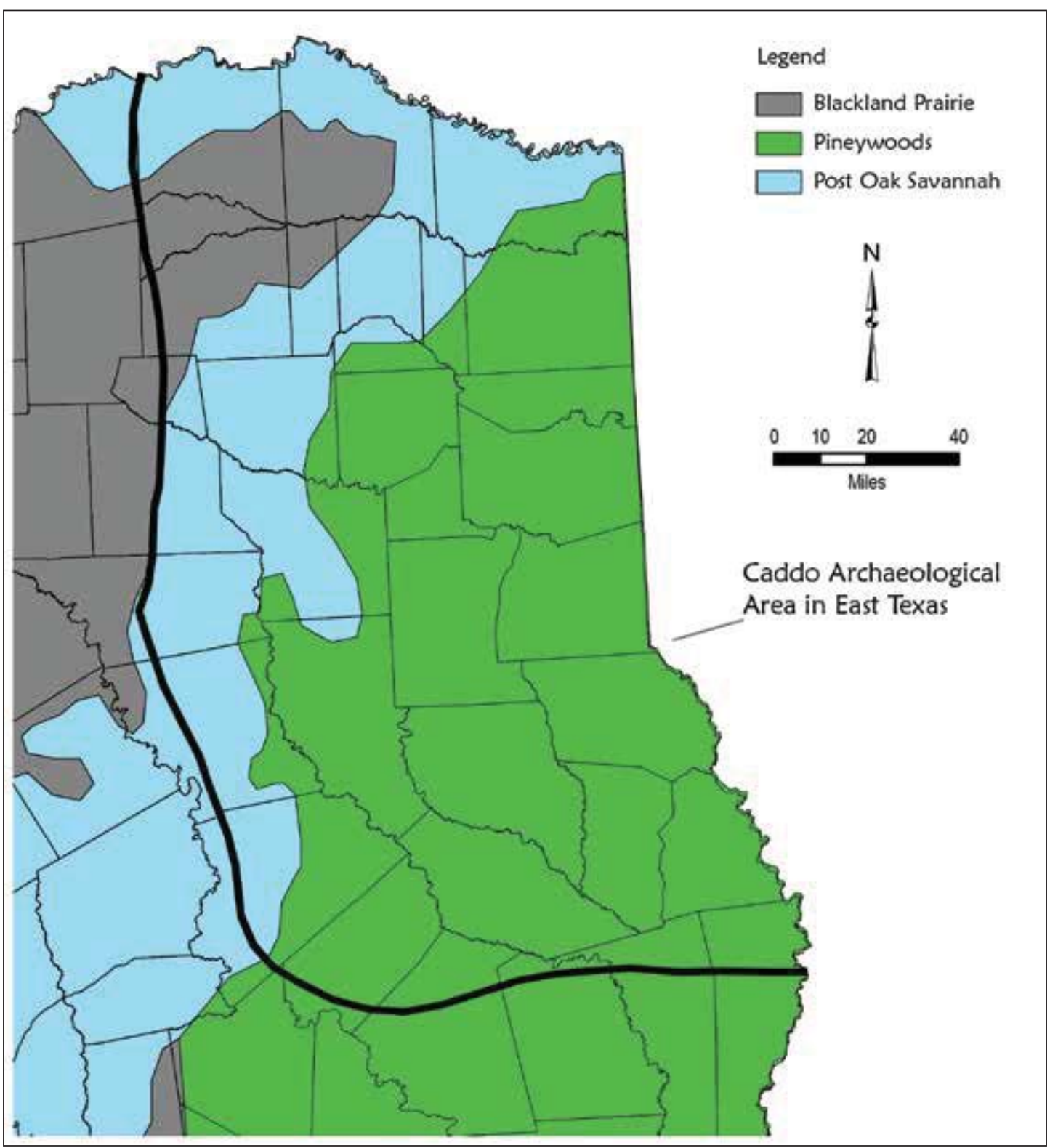

Figure 2. East Texas physiographic zones. Figure drawn by Sandra Hannum.

The Blackland Prairie is a zone of tall grass prairie, with little bluestem and Indiangrass, along with a riparian deciduous forest of oak, hickory, and other tree species, along major streams (such as the Trinity and Sulphur rivers) and their tributaries. The headwaters of the Sulphur, Sabine, and Trinity rivers originate in the Blackland Prairie (see Figure 2).

The modern climate of the East Texas region is humid, with a mean annual precipitation in modern times of at least 100-125 cm across the region as a whole. Periods of maximum rainfall occur in the spring and fall seasons. The growing season is about 260 days, with the last freeze occurring in March and the first freeze in late November. Droughts are also not uncommon in the modern era, and dendrochronological analyses of bald cypress tree rings for the last 1000 years suggest there were numerous wet and dry spells during that time (Stahle and Cleaveland 1994, 1995), including several lengthy droughts.

The climate in East Texas has changed dramatically over time and through the Holocene period, which has affected the biodiversity and plant and animal carrying capacity of the region. These changes in turn 
likely influenced the adaptations of Native American groups that lived in this broad region during the lengthy Archaic periods and after, especially as they may have become more dependent upon cultivated plants in what is a risky and occasionally drought-prone environment. A review of the paleoenvironmental record is appropriate to provide the context for the discussion that follows of the culture history of Native Americans living in East Texas between ca. 10,000-2500 years B.P.

Viau et al. (2002) have defined six different climatic episodes in North America between 12,000-1650 years ago that illustrate the considerable climatic variability that has occurred on the continent. These specific periods, as modified in more detailed discussion presented below based on climatic proxies and archeoclimatic modeling (Figures $3 \mathrm{a}-\mathrm{c}$ ) done by the Center for Climatic Research at the University of Wisconsin-Madison (Bryson and DeWall 2007); dendrochronological analyses (see Perttula 1999:Figure 2-5; Stahle and Cleaveland 1995); analysis of pollen cores (Holloway 1994; Albert 2007, 2011) for longterm changes in vegetation and periods of increased fire frequencies; reconstructed temperature variations (Crowley 2000), and reconstructed variation in atmospheric delta $\mathrm{C} 14$ due to changes in solar radiation (see Bradley et al. 2003:Figure 6-13; Perttula and Nelson 2004:7-9 and Figures 4 and 5), are directly relevant to the consideration of general paleoenvironmental change over the last 10,000 years in the Trans-Mississippi South and East Texas areas. These episodes are:

Younger Dryas (12,000-10,300 years ago), temperature declines; drier before 11,900 years ago and wetter around 10,900-10,300 years ago;

Boreal (10,300-8100 years ago), onset of the Holocene, warmer and wetter with mesic intervals and intensification of summer monsoons in the Southeast United States; significant cold event ca. 8200 years ago;

Atlantic I (8100-6700 years ago), drying trend with decreasing water tables and grasslands expanding east across the continent;

Atlantic II (6700-4300 years ago), increased summer mean temperatures and much drier, with eastward expansion of prairie; very dry ca. 4500-5000 years ago;

Sub-Boreal (4030-2850 years ago), climatic amelioration, with cooler and wetter climatic conditions; and

Sub-Atlantic (2850-1650 years ago), continued cooler climate with periods of widespread vegetation change in North America; very dry and cool episode ca. 2300-1800 years ago (in the early years of the Woodland period).

Pollen data from Ferndale Bog (Holloway 1994; see also Albert 1981; Ferring 1995) in the Ouachita Mountains of southeastern Oklahoma, and from several bogs in Central Texas (Bousman 1998), indicate that the Late Pleistocene climate (ca. 10,000-14,000 years ago) was cool (ca. 3-4 degrees cooler than modern times) and dry, and probably supported a grassland steppe. By ca. 10,000 years ago, as the climate became warmer and wetter, oak woodlands or oak savanna habitats would likely have been present throughout much of eastern Texas (and north into Oklahoma). These woodlands were maintained for at least a thousand years: perhaps even to as late as 8900 years ago, and Bousman (1998:Figure 4) notes a period of open, grassland vegetation in Central Texas between 9500-8750 B.P. The Ferndale Bog pollen diagram (see Ferring 1994:Figure 4.5) also points to a more open and grassy setting, based on decreasing oak pollen and a lower pollen influx between ca. 8000-9200 years ago, during the latter years of the Early Archaic period. In general, the period between ca. 8900-7340 years ago, the latter years of the Early Archaic and the first centuries of the Middle Archaic, was drier and warmer than the previous two millennia, with the notable exception of a cool event at ca. 8200 years ago. 


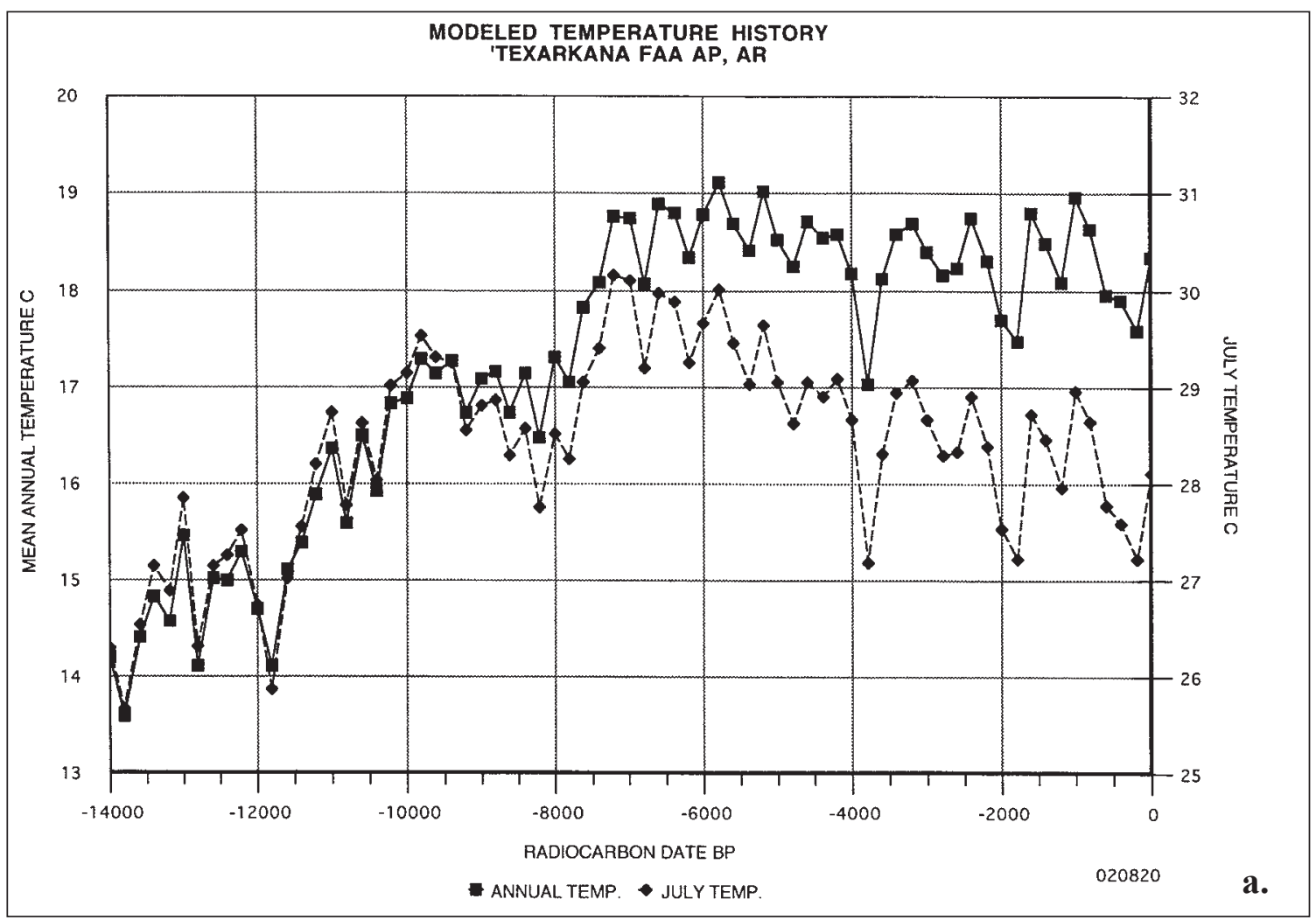

Figure 3. Models of temperature history, precipitation history, and water availability history for East Texas, ca. 14,000 to 0 years B.P. Graphs provided courtesy of Dr. Reid A. Bryson at the Center for Climatic Research, The University of Wisconsin-Madison: a, modeled temperature history; b, modeled precipitation history

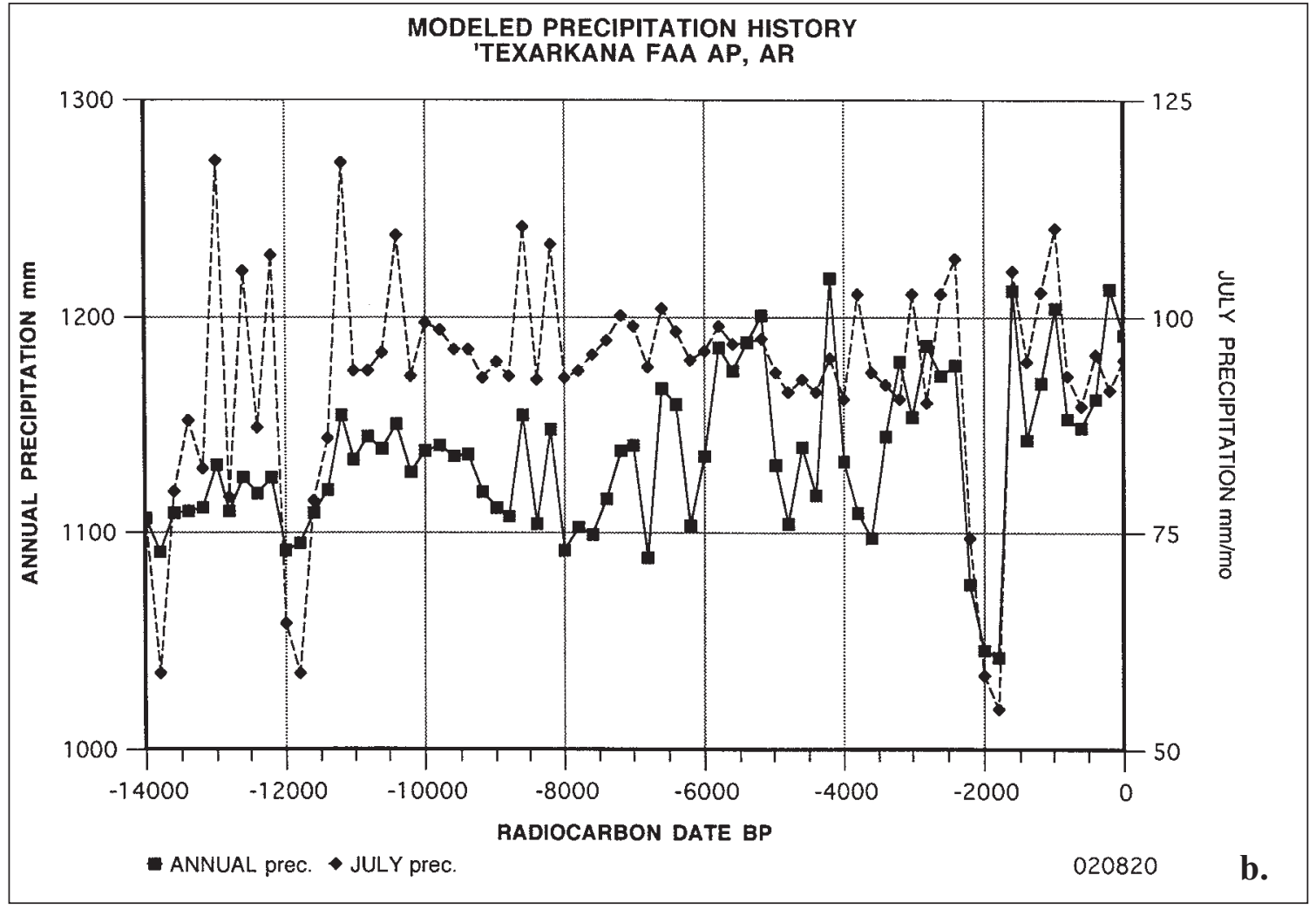




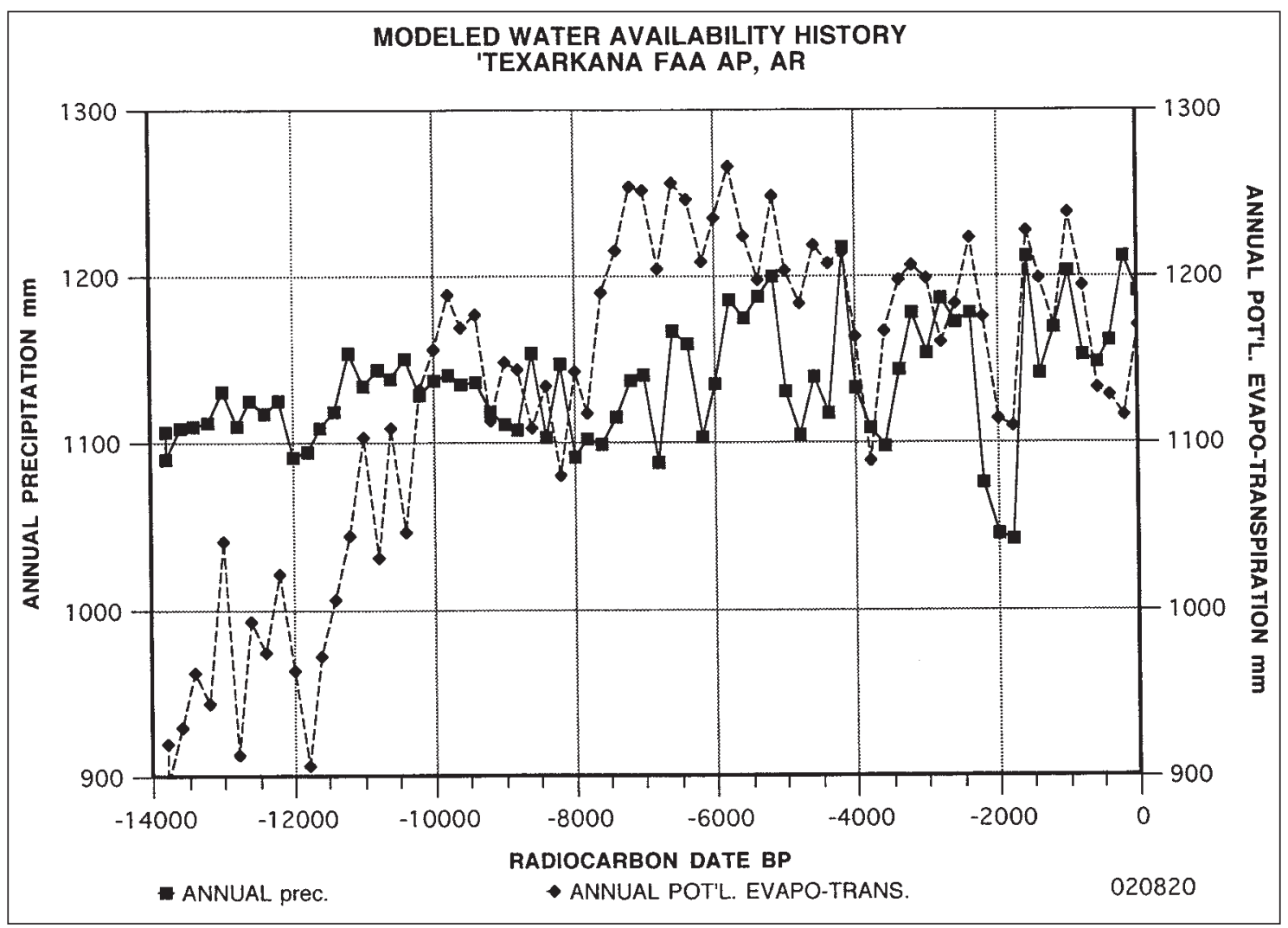

Figure 3c. Models of temperature history, precipitation history, and water availability history for East Texas, ca. 14,000 to 0 years B.P. Graphs provided courtesy of Dr. Reid A. Bryson at the Center for Climatic Research, The University of Wisconsin-Madison: modeled water availability history.

Continuing from ca. 7400 years ago until ca. 4500 years ago in the Atlantic I and II climatic periods, during much of the Middle Archaic and the early years of the Late Archaic, the Middle Holocene climate was predominantly quite warm (ca. 3 degrees warmer annually than today) and dry ( ca. $300 \mathrm{~mm}$ decrease), and Ferring (1995:24) suggests this was a period of significant reduction in available biomass for Native American hunter-gatherers in the region. In the Ferndale Bog area of southeastern Oklahoma, the vegetation was an oak-hickory-pine woodland, while farther to the south and west in Central Texas, grasslands were dominant. Bousman's (1998:210) palynological analyses led him to conclude that the grass cover was greatest - and the climate the driest - between 5500-4500 B.P., while Ferring (1995:24) placed the very dry and warmest episode between ca. 6500-5000 B.P. Coleman's (2009) reexamination of the Ferndale Bog pollen data led him to identify a cooler and mesic interval of bog formation between ca. 7300-5920 years ago (which would have consequently created significant increases in available biomass during this temporal interval), followed by very dry and warmer climatic conditions between ca. 5000-4500 years ago (at the start of the Late Archaic period).

Boulter's (2007:Tables 5.9 and 6.12) paleoenvironmental and geoarchaeological research on a variety of sandy mantle sites (on upland summits as well as on hill slope and valley bottoms) in eastern Texas has identified a considerable series of aeolian depositional events in the region since about 7800 years before the present (B.P.), including depositional events in the Archaic that date from 7280-7740 B. P., 6190-6640 B.P., 5900 B.P., 5480-5630 B.P. (a markedly hotter and/or drier episode, Boulter [2007:277]), 5200 B.P., 4600-4800 B.P., 4000-4200 B.P., 3400-3600 B.P., and 2800-3200 B.P. A number of the aeolian episodes can be bracketed against preceding and subsequent dated periods of soil formation and landscape stability at 10,000-9400 B.P., 8300-7500 B.P, 6200 B.P., 5500-4900 B.P., and 2900-2600 B.P. (Cranford et al. 
2009; Wyckoff et al. 2009) While the magnitude of each of these aeolian depositional events and soil formation episodes have not been established regionally, it does seem likely that sedimentation would have been sufficient over a broad span of time from these processes (aridity, increased wind speed, and a source of erosion-prone sandy sediments) to gradually, and likely slowly, bury prehistoric artifacts and traces of encampments at ancient occupational surfaces on the summit of upland landforms across the region (i.e., Frederick et al. 2002). So too, more mesic climatic intervals apparently enhanced episodic long-term soil formation and opportunities for landscape stability in the region during much of the Archaic.

The Late Holocene period, after ca. 5000-4500 years ago, appears to have been one of fluctuating climates - moist or dry cycles (ca. 100-200 mm changes in precipitation through each of the peaks and valleys) - and with generally wetter conditions than during the preceding Middle Holocene period. The climate was more like the modern climate in North America. Ferring and Yates (1998:Figure 7.5) proposed that in general between ca. 5000-2000 B.P. the climate was wetter. Climatic modeling (see Figure 3a) also suggests a very dry (ca. $200 \mathrm{~mm}$ decrease in annual precipitation) and cooler period between ca. 2300-1800 years ago, shortly after the onset of the Woodland period. With these fluctuating climatic and rainfall conditions, oak-hickory-pine woodlands were probably the principal vegetation in upland habitats in much of East Texas (as they are today), with a well-developed riverine forest in the floodplain settings (cf. Albert 2007). Plant and animal biomass would generally have been more abundant in Late Archaic times than was the case in the Middle Archaic.

Supporting the drier and warmer cycle in the middle portion of the Late Holocene, stable carbon and oxygen isotopes from mussel shells along Denton Creek in North Texas may point to a warm/dry peak at ca. 2850 B.P. (Brown 1998:164). Stable carbon isotope values from humate samples in the Cooper Lake area of the upper Sulphur River basin in East Texas have C4-enriched peaks (i.e., higher C4 grasses in the biomass) around 2000 B.P. and 4000 B.P. (see Perttula 1999:Figure 2-4).

\section{Temporal Context}

For the purposes of this article, and for use by archaeologists working in East Texas, I define the Archaic period in East Texas as lasting from 10,000 years B.P. to approximately 2500 years B.P., with the Early Archaic dating from ca. 10,000-8000 years B.P. (8050-6050 B.C.), the Middle Archaic ranging from $8000-5000$ years B.P. (6050-3050 B.C.), and the Late Archaic dating from 5000-2500 years B.P. (3050-550 B.C.). Except where specific radiocarbon dates are presented as cal B.P. or cal B.C., the chronological ages and dates in this article are the uncalibrated calendar ages in years B.P.

At the time of this compilation, a total of 25 East Texas sites with Archaic components have radiocarbon dates (Table 1); Table 1 includes specific information on the intra-site context of the radiocarbon-dated samples. There are only a total of 56 Archaic radiocarbon dates from these sites, with only one site - 41UR77_having as many as 14 dates on charred plant remains from deep archaeological deposits (Perttula and Ricklis 2005). None of the other Archaic sites/components have more than four radiocarbon dates (see also discussion of a slightly larger sample of dates from Archaic components in East Texas by Selden [2013]).

The few obtained Archaic radiocarbon dates is certainly limiting the ability to independently establish the ages of Archaic components, or even determine the absolute age of Archaic dart points and tools at East Texas sites. Nevertheless, the 56 radiocarbon dates represent a 100 percent increase from the last radiocarbon compilation for East Texas sites (Perttula 1997:Figure 1). That last compilation also indicated that there were more than 370 radiocarbon dates available from Caddo era sites (ca. A.D. 800-1800+) in East Texas, and that number has increased since then to at least 900 dates because of a number of well-dated post-1997 intensive testing and data recovery projects on Caddo sites in East Texas (see Selden and Perttula 2013a, 2013b). It is clear from the disparity in the number of radiocarbon dates from Archaic vs. Caddo sites where the research focus currently lies in East Texas. 
Table 1. Radiocarbon dates from East Texas Archaic Sites.

\begin{tabular}{|c|c|c|c|c|c|}
\hline \multirow[t]{2}{*}{ Site } & \multirow[t]{2}{*}{ Lab No. } & \multirow{2}{*}{$\begin{array}{l}\text { Conventional Age } \\
\text { (B.P.) }\end{array}$} & \multicolumn{2}{|c|}{ IntCal09 Calibration+ } & \multirow[t]{2}{*}{ Comments/Source } \\
\hline & & & $\begin{array}{l}1 \text { sigma } \\
\text { (B.P.) }\end{array}$ & $\begin{array}{l}2 \text { sigma } \\
\text { (B.P.) }\end{array}$ & \\
\hline $41 \mathrm{AN} 115$ & B-166266 & $3810 \pm 50$ & $4249-4146$ & $4410-4082$ & $\begin{array}{l}\text { Feature 1; Perttula (2002a); Fur- } \\
\text { man and Amick (2005) }\end{array}$ \\
\hline \multirow[t]{3}{*}{ 41BW692 } & UGA-13421 & N/A & - & $2850-2710^{*}$ & Lohse (2005), level 4 \\
\hline & UGA-13422 & N/A & - & $3840-3590^{*}$ & level 10 \\
\hline & UGA-13423 & N/A & - & $2950-2770^{*}$ & level 6 \\
\hline \multirow[t]{2}{*}{$41 \mathrm{CP} 220$} & B-204252 & N/A & - & $2830-2630^{*}$ & 70 cm bs; Perttula (2005) \\
\hline & B-204253 & N/A & - & $5290-4880^{*}$ & $80 \mathrm{~cm}$ bs \\
\hline \multirow[t]{2}{*}{$41 \mathrm{CS} 151$} & B-76608 & $2400 \pm 60$ & $2490-2348$ & $2621-2335$ & Feature 1; Perttula (1997) \\
\hline & B-81674 & $5300 \pm 60$ & $6185-5990$ & $6217-5924$ & Feature 23 \\
\hline 41DT59 & B-81670 & $2640 \pm 50$ & $2776-2743$ & $2847-2719$ & $\begin{array}{l}\text { Unit 31, level 5; Fields et al. } \\
\text { (1997) }\end{array}$ \\
\hline 41DT86 & SMU-532 & $9550 \pm 377$ & $11,280-10,272$ & $12,080-9855$ & Hearth; Perttula (1997) \\
\hline 41DT141 & B-17401 & $2350 \pm 81$ & $2461-2331$ & $2619-2155$ & $\begin{array}{l}\text { 4Ab2 zone; Fields et al. } \\
\text { (1997) }\end{array}$ \\
\hline 41FN66 & B-205705 & $4250 \pm 90$ & $4867-4809$ & $4979-4528$ & $\begin{array}{l}\text { Unit 2; Bousman and Skinner } \\
\text { (2007); Skinner et al. (2005) }\end{array}$ \\
\hline 41HP106 & B-83089 & $2800 \pm 70$ & $2970-2842$ & $3078-2759$ & Feature 64; Perttula (1999) \\
\hline \multirow[t]{2}{*}{ 41HP118 } & SMU-1883 & $2860 \pm 70$ & $3075-2873$ & $3211-2790$ & $220 \mathrm{~cm}$ bs; Fields et al. (1997) \\
\hline & SMU-1970 & $2980 \pm 30$ & $3214-3110$ & $3259-3072$ & 2A2b zone; Fields et al. (1997) \\
\hline \multirow[t]{4}{*}{ 41HP159 } & SMU-2222 & $4800 \pm 90$ & $5604-5336$ & $5714-5317$ & Feature 1; Fields et al. (1997) \\
\hline & GX-15878 & $4490 \pm 70$ & $5302-5032$ & $5319-4869$ & Feature 12 \\
\hline & GX-15880 & $4990 \pm 70$ & $5882-5645$ & $5909-5592$ & Unit $43,170-180 \mathrm{~cm} \mathrm{bs}$ \\
\hline & GX-15881 & $5540 \pm 70$ & $6404-6285$ & $6450-6278$ & Unit $45,180-190 \mathrm{~cm} \mathrm{bs}$ \\
\hline 41HS846 & B-210250 & $3550 \pm 40$ & $3779-3890$ & $3718-3963$ & $\begin{array}{l}\text { Unit } 13,50-60 \mathrm{~cm} \text {; Gadus et al. } \\
\text { (2006) }\end{array}$ \\
\hline 41NA236 & B-204781 & $4290 \pm 40$ & $4864-4838$ & $4878-4827$ & Feature 13; Perttula (2008) \\
\hline 41NA240 & B-151100 & $2720 \pm 40$ & $2854-2768$ & $2880-2754$ & $\begin{array}{l}\text { Unit } 4,60-80 \mathrm{~cm} \text { bs; Perttula } \\
\text { (2002b) }\end{array}$ \\
\hline 41NA264 & B-151106 & $3090 \pm 80$ & $3384-3214$ & $3462-3076$ & $\begin{array}{l}\text { Unit } 8,50-70 \mathrm{~cm} \text { bs; Perttula } \\
(2002 \mathrm{~b})\end{array}$ \\
\hline 41NA285 & B-151111 & $3780 \pm 40$ & $4232-4090$ & $4249-3996$ & $\begin{array}{l}\text { Unit } 7 / 10 / 12,60-80 \mathrm{~cm} \text {; Perttula } \\
(2002 \mathrm{~b})\end{array}$ \\
\hline \multirow[t]{2}{*}{ 41NA290 } & B-151114 & $3190 \pm 70$ & $3469-3360$ & $3568-3264$ & $\begin{array}{l}\text { Unit } 7 / 10,30-50 \mathrm{~cm} \text { bs; Perttula } \\
(2002 \mathrm{~b})\end{array}$ \\
\hline & B-151115 & $2930 \pm 110$ & $3259-2925$ & $3376-2785$ & $\begin{array}{l}\text { Unit } 7 / 10,70-90 \mathrm{~cm} \text { bs; Perttula } \\
(2002 \mathrm{~b})\end{array}$ \\
\hline
\end{tabular}


Table 1. Radiocarbon dates from East Texas Archaic Sites, cont.

\begin{tabular}{|c|c|c|c|c|c|}
\hline \multirow[t]{2}{*}{ Site } & \multirow[t]{2}{*}{ Lab No. } & \multirow{2}{*}{$\begin{array}{l}\text { Conventional Age } \\
\text { (B.P.) }\end{array}$} & \multicolumn{2}{|c|}{ IntCal09 Calibration+ } & \multirow[t]{2}{*}{ Comments/Source } \\
\hline & & & $\begin{array}{l}1 \text { sigma } \\
\text { (B.P.) }\end{array}$ & $\begin{array}{l}2 \text { sigma } \\
\text { (B.P.) }\end{array}$ & \\
\hline & B-151117 & $3020 \pm 40$ & $3268-3164$ & $3345-3100$ & $\begin{array}{l}\text { Unit } 7 / 10,90-110 \mathrm{~cm} \text { bs; Perttu- } \\
\text { la }(2002 \mathrm{~b})\end{array}$ \\
\hline & B-151118 & $2940 \pm 40$ & $3164-3060$ & $3219-2962$ & $\begin{array}{l}\text { Unit } 7 / 10,110-130 \mathrm{~cm} \text { bs, Pert- } \\
\text { tula }(2002 \mathrm{~b})\end{array}$ \\
\hline 41PN175 & B-163092 & $2980 \pm 40$ & $3135-3230$ & $3060-3322$ & $\begin{array}{l}\text { Feature 5; Cliff and Perttula } \\
2002\end{array}$ \\
\hline \multirow[t]{2}{*}{ 41RK215 } & B-60089 & $3090 \pm 90$ & $3390-3211$ & $3474-3066$ & level 6; Perttula (1997) \\
\hline & B-60090 & $3560 \pm 90$ & $3977-3717$ & $4090-3635$ & level 8 \\
\hline \multirow[t]{4}{*}{ 41RK222 } & B-72775 & $2490 \pm 190$ & $2768-2340$ & $2970-2113$ & Feature 11; Rogers et al. (2001) \\
\hline & B-72777 & $2440 \pm 70$ & $2707-2353$ & $2747-2340$ & Feature 13 \\
\hline & B-72779 & $3180 \pm 130$ & $3558-3317$ & $3963-3072$ & Feature 18 \\
\hline & B-72780 & $2890 \pm 60$ & $3110-2948$ & $3214-2860$ & Feature 18, AMS \\
\hline \multirow[t]{2}{*}{ 41RK468 } & B-239707 & $3180 \pm 40$ & $3445-3368$ & $3469-3345$ & Feature 1, Dixon et al. (2008) \\
\hline & B-239709 & $2520 \pm 40$ & $2732-2692$ & $2759-2467$ & Feature 3 \\
\hline 41TT392 & B-64978 & $3320 \pm 60$ & $3635-3469$ & $3693-3405$ & level 6; Perttula (1997) \\
\hline $41 \mathrm{TT} 396$ & B-64979 & $3620 \pm 70$ & $3990-3840$ & $4097-3722$ & level 3; Perttula (1997) \\
\hline \multirow[t]{3}{*}{$41 \mathrm{TT} 550$} & B-70991 & $2530 \pm 60$ & $2743-2682$ & $2756-2361$ & level 7; Perttula (1997) \\
\hline & B-70992 & $2600 \pm 60$ & $2759-2719$ & $2790-2692$ & level 8 \\
\hline & B-71230 & $2590 \pm 60$ & $2756-2715$ & $2785-2682$ & level 9 \\
\hline \multirow[t]{14}{*}{ 41UR77 } & UGA-12972 & $2950 \pm 40$ & $3168-3066$ & $3249-2970$ & $\begin{array}{l}\text { level 8, Perttula and Ricklis } \\
\text { (2005); levels are in different } \\
\text { units and trenches }\end{array}$ \\
\hline & UGA-12973 & $3490 \pm 40$ & $3833-3696$ & $3867-3642$ & level 13 \\
\hline & UGA-12974 & $2580 \pm 40$ & $2749-2719$ & $2759-2702$ & level 9 \\
\hline & UGA-12975 & $5220 \pm 50$ & $5996-5920$ & $6029-5906$ & level 15 \\
\hline & UGA-12976 & $4220 \pm 50$ & $4844-4813$ & $4860-4614$ & level 17 \\
\hline & UGA-12977 & $4360 \pm 40$ & $4971-4860$ & $5041-4847$ & level 13 \\
\hline & UGA-12978 & $4180 \pm 50$ & $4832-4787$ & $4847-4532$ & level 16 \\
\hline & UGA-12979 & $4630 \pm 40$ & $5326-5311$ & $5467-5298$ & level 9 \\
\hline & UGA-12980 & $3130 \pm 40$ & $3389-3340$ & $3442-3263$ & $125-150 \mathrm{~cm} \mathrm{bs}$ \\
\hline & UGA-12981 & $3210 \pm 40$ & $3462-3389$ & $3482-3363$ & $150-175 \mathrm{~cm} \mathrm{bs}$ \\
\hline & UGA-12982 & $3140 \pm 40$ & $3390-3345$ & $3455-3267$ & $175-200 \mathrm{~cm} \mathrm{bs}$ \\
\hline & UGA-12985 & $2860 \pm 40$ & $3060-2925$ & $3100-2867$ & Feature 1 \\
\hline & B-166911 & $4130 \pm 60$ & $4823-4528$ & $4838-4443$ & Zone $3,100-110 \mathrm{~cm}$ bs \\
\hline & B-166912 & $7020 \pm 40$ & $7875-7800$ & $7940-7762$ & Zone $4,140-150 \mathrm{~cm}$ bs \\
\hline
\end{tabular}

UGA=University of Georgia; B=Beta Analytic, Inc.; SMU=Southern Methodist University; + Reimer et al. (2009); *Not calibrated using IntCal09; calibration method or reference not specified in Lohse (2005) or Perttula (2005) 
The 56 radiocarbon dates from Archaic sites and components in East Texas summarized herein are from Early Archaic ( $\mathrm{n}=1,1.8$ percent), Middle Archaic ( $\mathrm{n}=4,7.1$ percent), and Late Archaic ( $\mathrm{n}=51,91.1$ percent) archaeological contexts and features (see Table 1). Selden (2013:66) notes that there is a "fairly remarkable increase in the number of dates during the Late Archaic...period following a sparse dated record for the Early and Middle Archaic." That the vast majority of the radiocarbon dates are from Late Archaic contexts suggests that sites of this age are particularly common in the region, and that sites of this age are also visible on the landscape in surface and near-surface contexts, and are readily identified during archaeological survey and test excavation work. It is also clear that very few Archaic sites in East Texas have been recommended by state and federal agencies for data recovery in the last 20 years, making it difficult to establish more reliable chronological sequences for the Archaic archaeological record, among other things.

Only three East Texas sites with Archaic archaeological components have optically stimulated luminescence (OSL) dates (Table 2). The two OSL dates from 41UR77 are compatible with the radiocarbon dates obtained from deep Archaic deposits there (see Table 1), and they help demonstrate that Middle to Late Archaic archaeological deposits and associated material culture remains are buried in alluvial deposits at this site along Big Sandy Creek (Perttula and Ricklis 2005). Perhaps this dating technique may be more profitably used in the future as a means of obtaining absolute dates from Archaic (and earlier) archaeological sites in the region.

Table 2. OSL Dates from Archaic Sites in East Texas.

\begin{tabular}{|c|c|c|c|}
\hline Site & $\begin{array}{l}\text { OSL Dates } \\
\text { (B.P.) }\end{array}$ & $\begin{array}{l}\text { Age Range } \\
\text { (2 sigma, B.P.) }\end{array}$ & Source \\
\hline \multirow[t]{16}{*}{$41 \mathrm{AN} 38$} & $7760 \pm 33$ & $7826-7694$ & $\begin{array}{l}20 \mathrm{~cm} \mathrm{bs} \text {; Bateman } \\
(2011) \text {, Column } 1\end{array}$ \\
\hline & $4040 \pm 20$ & $4080-4000$ & $30 \mathrm{~cm} \mathrm{bs}$ \\
\hline & $3910 \pm 19$ & $3948-3872$ & $40 \mathrm{~cm} \mathrm{bs}$ \\
\hline & $7790 \pm 44$ & $7878-7702$ & $45 \mathrm{~cm} \mathrm{bs}$ \\
\hline & $3530+19$ & $3568-3492$ & $50 \mathrm{~cm} \mathrm{bs}$ \\
\hline & $7400 \pm 35$ & $7470-7330$ & $55 \mathrm{~cm} \mathrm{bs}$ \\
\hline & $9500 \pm 39$ & $9578-9422$ & $60 \mathrm{~cm} \mathrm{bs}$ \\
\hline & $9020 \pm 32$ & $9084-8956$ & $65 \mathrm{~cm} \mathrm{bs}$ \\
\hline & $4870 \pm 24$ & $4918-4822$ & 35 cm bs; Column 2 \\
\hline & $5720 \pm 29$ & $5778-5662$ & $40 \mathrm{~cm} \mathrm{bs}$ \\
\hline & $7230 \pm 30$ & $7290-7170$ & $45 \mathrm{~cm} \mathrm{bs}$ \\
\hline & $9260 \pm 53$ & $9366-9154$ & $50 \mathrm{~cm} \mathrm{bs}$ \\
\hline & $6590+58$ & $6706-6474$ & $55 \mathrm{~cm} \mathrm{bs}$ \\
\hline & $4260 \pm 31$ & $4322-4198$ & $60 \mathrm{~cm} \mathrm{bs}$ \\
\hline & $7370 \pm 28$ & $7426-7314$ & $65 \mathrm{~cm} \mathrm{bs}$ \\
\hline & $11,33 \overline{0} \pm 42$ & $11,414-11,246$ & $70 \mathrm{~cm} \mathrm{bs}$ \\
\hline 41HS606 & $5420 \pm 76$ & $5752-5268$ & 80 cm bs; Keller (1998) \\
\hline \multirow[t]{2}{*}{ 41UR77* } & $2800 \pm 15$ & $2830-2770$ & $\begin{array}{l}82 \mathrm{~cm} \text { bs; Perttula and } \\
\text { Ricklis (2005) }\end{array}$ \\
\hline & $7800+39$ & $7878-7722$ & $148 \mathrm{~cm} \mathrm{bs}$ \\
\hline
\end{tabular}

*The other three OSL dates, from depths of $230-368 \mathrm{~cm}$ bs, range from 18,400 to 23,400 years B.P. (Bateman 2005:Table 27). 
Archaeological data from the Yarbrough site (41VN6) on the upper Sabine River in East Texas were employed by Johnson (1962) to first bring a measure of chronological and cultural order to the diverse Archaic archaeological record found in Northeast Texas. Of particular import were Johnson's (1962:208) temporal divisions of the Archaic based on projectile point sequences at this deep midden site, and the introduction of plain Woodland period ceramics at the end of the period. Unfortunately, Johnson's scheme was not tied to any radiocarbon-dated archaeological deposits at this or other East Texas sites, and it has proven difficult since to establish the chronological basis of his postulated projectile point sequences. The same may be said for projectile point sequences proposed by Story (1990) and Thurmond (1990).

Nevertheless, I suggest a temporal ordering of dart points in the East Texas Archaic in Figure 4. This temporal ordering has drawn first upon the previously mentioned and few available absolute dates from East Texas on Archaic sites, as well as the known sequences of dart points in surrounding regions, such as Southwest Arkansas (Schambach 1998; Trubitt 2009), Northwest and Northern Louisiana (Girard 2000; Girard et al. 2011; Anderson and Smith 2003; Rees 2010; Saunders 2010), the Missouri Ozarks (Ray et al. 2009), and Central Texas (Collins 1998; Collins et al. 2011), and chronological periods of use offered by Turner and Hester (1999). Finally, I relied upon a recent cladistics study (see O'Brien and Lyman [2003] and Lipo et al. [2006] for considerations of cladistics and archaeological studies) of 93 Texas dart point types that has plotted the statistical affinities among the various dart point types (Carpenter and Paquin 2010:158 and Figures 2 and 3). From these relationships, Carpenter and Paquin (2010:Figure 4) proposed hypothetical relationships between dart point types "based on overlap in temporal, spatial, and formal attributes." In other words, it is useful to "regard sequences of types as arbitrary subdivisions of continuous chronotypes" (Shott 2015:51).

In creating Figure 4, then, I employed the hypothetical relationships between types detected in the Carpenter and Paquin (2010) cladistics study, focusing only on those dart part types (see Suhm and Jelks 1962) known to have been made and used at various times in the East Texas Archaic (even if they were not included in Carpenter and Paquin [2010]), regardless of the spatial distributions of certain points (i.e., Evans, Pontchartrain, Epps, Rice Lobed, or Jakie Stemmed) that suggested some types were common in the archaeological record in one or more surrounding states. Known temporal ages of these additional projectile point types were used to place them in their best approximate age on Figure 4.

Based on these various lines of evidence, as well as the suggested chronological sequences for East Texas dart points proposed by Story (1990:Figure 32) and Thurmond (1990:Table 8), the Early Archaic dart point sequence begins with Dalton and San Patrice points, although both point types were first made sometime prior to 10,000 years B.P. (Koldehoff and Walthall 2009; Morse 1997; Ray et al. 2009) and are often considered to be diagnostic of the Late Paleoindian period in the broader region. Recent radiocarbon dates from the Big Eddy site in southwest Missouri indicates both points were made and used until ca. 9800 years B.P. (Ray et al. 2009:160), in the early years of the Late Paleoindian-Early Archaic technological, subsistence, and settlement/mobility transition (cf. Bousman et al. 2002:989). Later Early Archaic points (ca. 9800-9000 years B.P.) include the Breckenridge, Scottsbluff, and Keithville types (Webb 2000:4), as well as later Pelican ${ }^{1}$, Graham Cave, and Rice Lobed points (ca. 8500-8000 years B.P.).

Proposed early Middle Archaic points in East Texas include the Hidden Valley and Kirk types, as well as the Palmer type, although these are points that are not particularly common in East Texas dart point assemblages (e.g., Jones 1957; Rogers and Perttula 2004; Furman and Amick 2006; Turner 2006:Table 7). Between 6500-5000 years B.P., Middle Archaic points are suggested to include the Cossatot, Johnson, Jakie Stemmed, White River side-notched points (sometimes referred to as Big Sandy points, see Ray and Lopinot 2003), Morrill, Bell and Andice (or Calf Creek), and the distinctive blade-notched Evans point (see Figure 4).

In the early part of the Late Archaic period (ca. 5000-4000 years B.P.), East Texas dart point assemblages may be expected to include Bulverde, Carrollton, Wells, Williams, and Trinity types, as well as Palmillas and Neches River (see Figure 4). This is the beginning of the greatest typological richness in dart points in East Texas archaeological sites, perhaps suggesting changes in transmission processes or the technology of 


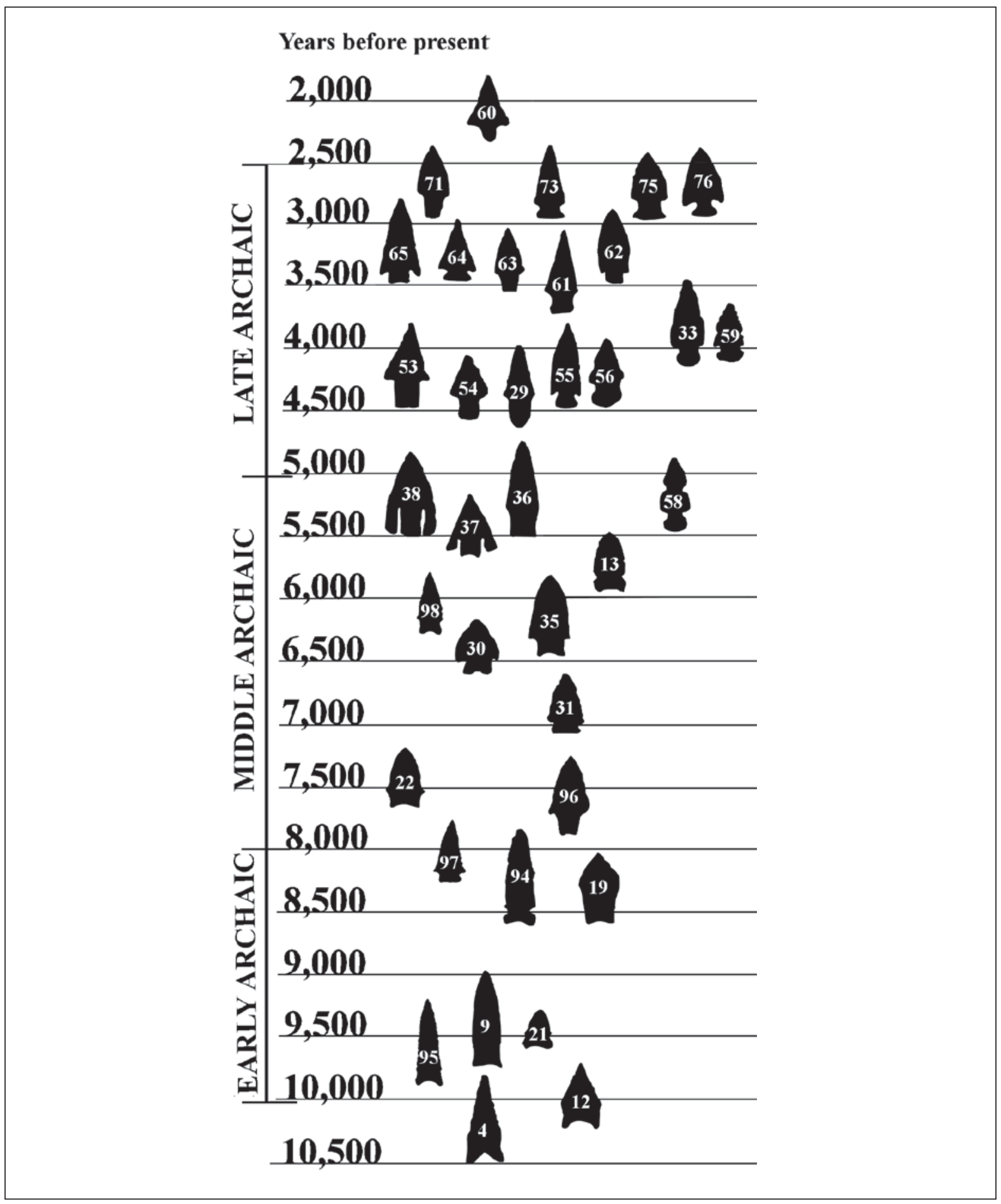

Figure 4. Proposed temporal ordering of dart points in the East Texas Archaic, ca. 10,000-2500 years B.P. (after Carpenter and Paquin 2010). Key to projectile point types on Figure 4: 4. Dalton; 9. Scottsbluff; 12. San Patrice; 13. White River; 19. Pelican; 21. Keithville, or San Patrice, var. Keithville; 22. Kirk; 29. Wells; 30. Cossatot; 31. Palmer; 33. Palmillas; 35. Johnson; 36. Morrill; 37. Bell; 38. Andice; 53. Bulverde; 54. Carrollton; 55. Williams; 56. Trinity; 58. Evans; 59. Neches River; 60. Gary; 61. Yarbrough; 62. Pontchartrain; 63. Kent; 64. Ellis; 65. Marshall; 71. Dawson; 73. Godley; 75. Epps; 76. Motley; 94. Graham Cave; 95. Breckenridge; 96. Hidden Valley; 97. Rice Lobed; 98. Jakie. Figure drawn by Lance Trask, based in part on Carpenter and Paquin (2010). 
dart point delivery systems. Dart points posited to date primarily to the latter part of the Late Archaic (ca. 3800-2500 years B.P.) include Yarbrough (although the dating evidence for this point type is contradictory on East Texas sites), Pontchartrain, Kent, Ellis, and Marshall types, as well as Dawson, Godley, Epps, and Motley types (see Figure 4). The ubiquitous contracting stem Gary point appears to have been made and used beginning at the end of the Late Archaic (cf. Schambach 1998), but fully flourished as a dart point/ knife throughout the later Woodland period.

\section{Early Archaic period}

For the period prior to about 9500-9800 years B.P., the East Texas archaeological record primarily consists of surficial, mixed, or isolated finds of diagnostic projectile points such as Dalton (Figure 5a-b), San Patrice, and Scottsbluff (cf. Johnson 1989; Perttula 2013; Perttula and Young 2012; Story 1990). The temporal and stylistic classifications of these projectile points is based primarily on comparisons with welldated and stratified sites to the east and west of the region (see Anderson and Sassaman 2012; Collins 1998; Emerson et al. 2009; Trubitt 2009).
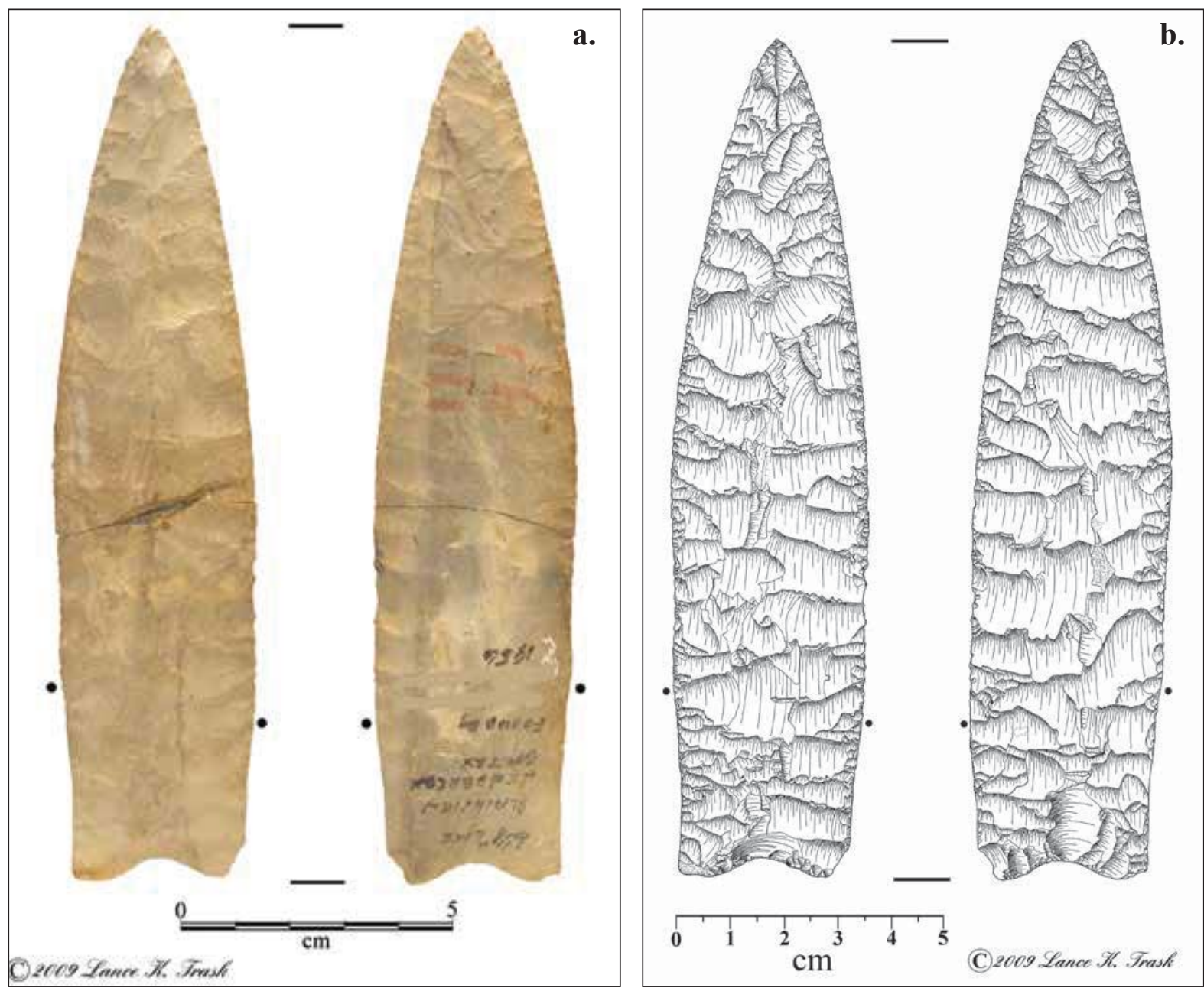

Figure 5. Dalton point from a Henderson County, Texas site in the William L. Young collection: a, photograph; $\mathrm{b}$, drawing of the point. This oversized Dalton point may have been associated with an individual that had a connection with an earth deity/spirit (Claassen 2015:169). 
Sites with these types of dart points are common throughout East Texas (Bousman et al. 2004:Figures 2.46e, $\mathrm{h}-\mathrm{i}$ ). At the Forrest Murphey site (41MR62), for example, Clovis, Plainview, Dalton, and other lanceolate projectile point forms and tools were found in several discrete concentrations on a high terrace above Big Cypress Creek; faunal remains from extinct elephants were also recovered in apparent association (Story 1990). The Delta Bone Quarry 5 (41DT86) on the North Sulphur river had a buried hearth and an antler tool (Slaughter and Hoover 1965), and charcoal from the hearth has a calibrated two sigma age range of 11,280-10,272 years B.P., broadly contemporaneous with Dalton and/or San Patrice complexes in the region.

Undoubtedly other discrete archaeological components are present in the region, such as the buried Finley Fan site in the Sulphur River basin occupied as early as 5600 years B.P. (Gadus et al. 1992), and the spatially discrete San Patrice Culture John Pearce site in the Red River basin in northwestern Louisiana (Webb et al. 1971), but they have proven to be quite difficult to define and recognize. For example, a site has been reported by avocational archaeologists in deep sand deposits on the Neches River where it had been apparently exposed by Lake Palestine shoreline erosion. Thirty-five lanceolates, primarily Dalton and Scottsbluff forms (suggesting an occupation that may have ended ca. 9800 years B.P.), projectile point preforms, drills, and scrapers comprise the recovered assemblage, with most of the tools manufactured on cherts from the Edwards Plateau of Central Texas and Ouachita Mountains cherts and quartzites from southeastern Oklahoma and the Red River gravels (Perttula 1989). In another case, McCrocklin (1994 personal communication) has documented Dalton and early side-notched points, knives, scrapers, bone tools (antler flakers), and cut bone (some fossilized) from blue clay deposits buried in a Red River gravel bar north of Shreveport, Louisiana. Similar material culture remains have been documented from the Twin Bird Islands site (16CD118) in the Red River basin (Pevny 2014; Boulanger et al. 2014).

Unfluted lanceolates - usually resharpened and beveled - dominate the material culture record in the region between ca. 10,500-9500 years B.P. This includes Dalton (Johnson 1989:Figure 7; Wyckoff and Bartlett 1995), the related Breckenridge, San Patrice (Jennings 2008a, 2008b; Webb et al. 1971), and Scottsbluff points which are concentrated in East Texas and locales to the east (e.g., Saunders and Allen 1997:Figure 2), as well as early side-notched points and Albany beveled bifaces or knives (see Webb et al. 1971; Johnson 1989:Figure 13), Quince-style scrapers, end and side scrapers, denticulates, burins, and bifacial adzes. San Patrice projectile points and associated tools are typically manufactured on local raw materials (Saunders and Allen 1997:3; Webb et al. 1971), at least in sites then situated in the woodlands (see Jennings 2008a, 2008b). In plains San Patrice sites, about 21 percent of the San Patrice points are made from exotic raw material sources compared to only 6 percent of the San Patrice points from woodland contexts (Jennings 2008a:Table 7). There is a marked preference for the use of non-local lithic raw materials in other Late Paleoindian-Early Archaic chipped stone tools, however.

The distribution of Early Archaic sites within the region suggests that these early occupations were principally situated within the valleys of major stream basins (see Thurmond 1990:Table 53 and 54; Anderson 1996a), as well as in resource-rich areas like the Ouachita Mountains escarpment (Anderson 1996b:Figure 3.2). It appears that foraging groups occupied small camps and had an unspecialized hunting tool kit. It has been postulated that the initial and most intensive Paleoindian settlement of the Southeast U.S. (which would include East Texas) took place in the resource-rich valleys of the Mississippi River and its principal tributaries (such as the Red River). From there, groups settled throughout the wooded Southeast and East, with concentrations at $250-400 \mathrm{~km}$ intervals, indicating the scale of movement of these highly mobile foragers. The relatively sparse Early Archaic archaeological record, in conjunction with the dispersion of artifacts on many landforms and different settings within the region, seems to indicate that the aboriginal groups at this time were very mobile hunters and gatherers consuming a diversity of plant and animal foods rather than specialized hunters of extinct megafauna or other large game animals (Fields and Tomka 1993:82). Johnson (1989) also suggested that some of the early Archaic archeological remains (Plainview and Scottsbluff projectile points, and Cody knives) from the region are a result of Plains Early Archaic (ca. $10,000-9,000$ years ago) groups that moved into parts of Northeast Texas, during periods when grassland habitat spread eastward, to exploit the plains resources (such as bison) found there. The wide distribution 
of Scottsbluff projectile points in East Texas and adjoining parts of the Trans-Mississippi South (Bousman et al. 2004:Figure 2.46i; Bousman and Oksanen 2012:Figure 9.19) cast considerable doubt on the Plains origins of the aboriginal peoples that made and used this style of lanceolate point.

\section{Middle Archaic period}

Recent paleoenvironmental research suggests that during much of the Archaic (see above), particularly the period between ca. 8000-5000 years ago, it was drier than today (Bousman and Oksanen 2012:Figure 9.2), with apparent and punctated reductions in biomass as well as the local expansion of prairie habitats along the western and northern margins of the region (see Figure 1). Nevertheless, drier conditions and changing vegetation conditions "clearly did not preclude occupations" (Ferring 1995:33) during these periods. While the archaeological data are still rather limited, it appears that group mobility remained high for these hunting-gathering foragers (who utilized hardwood nuts, deer, shellfish, turtles, and small mammals) during the Middle Archaic period, and they were likely to have begun the bulk processing of the nut mast (e.g., Moore and Dekle 2010). At the Conley site (16BI19) on a tributary to the Red River in northwestern Louisiana, a ca. 7100-8300 year old occupation (based on a number of calibrated dates, Table 3), the Middle Archaic groups there "focused on deer and slack water aquatic species, but a wide range of resources, from varied microenvironments, was exploited" (Girard 2000:63; see also Girard et al. 2011). Hickory nuts and acorns were also common in the archaeological deposits.

Table 3. Radiocarbon dates from the Conly Site (16BI19) in Northwest Louisiana.

\begin{tabular}{|c|c|c|c|c|}
\hline \multirow[t]{2}{*}{ Lab No. } & \multirow{2}{*}{$\begin{array}{l}\text { Conventional Age } \\
\text { (B.P.) }\end{array}$} & \multicolumn{2}{|c|}{ IntCa109 Calibration+ } & \multirow[t]{2}{*}{ Comments/Source } \\
\hline & & $\begin{array}{l}1 \text { sigma } \\
\text { (B.P.) }\end{array}$ & $\begin{array}{l}2 \text { sigma } \\
\text { (B.P.) }\end{array}$ & \\
\hline B-139001 & $6050 \pm 190$ & $6670-7167$ & $6445-7330$ & Feature 3 \\
\hline B-139002 & $6730 \pm 260$ & $7442-7835$ & $7162-8027$ & Feature 7 \\
\hline UGA-8828 & $6650 \pm 40$ & $7500-7572$ & $7462-7585$ & Feature 7 \\
\hline UGA-8829 & $6680 \pm 40$ & $7560-7581$ & $7485-7609$ & Burial 3 \\
\hline B-131762 & $6710 \pm 40$ & $7569-7592$ & $7510-7621$ & $\begin{array}{l}\text { Midden above Feature 19; } \\
\text { Girard (2000) }\end{array}$ \\
\hline B-138999 & $6950 \pm 70$ & $7687-7852$ & $7662-7937$ & Feature 19 \\
\hline B-139003 & $6940 \pm 60$ & $7687-7840$ & $7666-7930$ & Feature 17 \\
\hline B-139000 & $7140 \pm 160$ & $7827-8065$ & $7666-8322$ & Burial 2 area \\
\hline GX-29255 & $6920 \pm 40$ & $7790-7695$ & $7840-7670$ & Feature 21 \\
\hline
\end{tabular}

UGA=University of Georgia; B=Beta Analytic, Inc.

+ Reimer et al. (2009)

Group territories were large and poorly defined, with most sites conforming to what Thurmond (1990:41) called "heavy" and "limited-use" areas; that is, repeated and recurrent occupations by small groups. Anderson (1996a) suggests that such Middle Archaic groups had highly mobile foraging adaptations along the Red River, the central Sabine River, and in interior uplands away from major drainages, with expedient lithic technologies. Most sites of this age were briefly used, but tended to be concentrated in the larger drainages within the region.

Sometime during the Middle Archaic period, fairly substantial and extensive occupations are recognized within the major basins in the region, with a rather limited use of smaller tributaries and headwater areas. Components of this period are open camps dominated by hunting tools, including the distinctive blade notched Evans point, although not a common temporal diagnostic, at least in East Texas when compared to Northwest Louisiana (see Saunders 2010), and generalized cutting/scraping tools, debris, ground stone tools, and cores. One unrecorded site in Gregg County found by Buddy C. Jones, that may date from ca. 
6500-5700 years B.P. based on comparisons with other sites with similar kinds of dart points in occupations with radiocarbon dates, contains an abundance of Middle Archaic White River side-notched points made from novaculite, Cossatot points, as well as a Jakie Stemmed point on a local raw material (Perttula 2004:Figure 13.4).

Burned rock features (possible hearths, ovens, and cooking pits?) and burned rock concentrations (cf. Black and Thoms 2014) are present in dated late Middle Archaic contexts at a few sites in the Sulphur River drainage (see Gadus et al. 1992; Cliff et al. 1996), suggesting that an important activity was the cooking and bulk processing of plant foods, but mainly by small groups for short-term use (Fields et al. 1997:90) as large burned rock middens are not known in the region. A single burned rock feature at the Unionville site (41CS151) has a calibrated age range of 6217-5924 B.P., during the latter part of the Middle Archaic period (Cliff et al. 1996).

Lithic raw material data from a possible Middle Archaic assemblage at Lake Fork Reservoir in the upper Sabine River basin indicates that the exchange of non-local materials (particularly finished tools) was commonplace (Perttula 1984), although "patterns in raw material use were not uniform across Northeast Texas" (Fields and Tomka 1993:92), but in general, the use of non-local raw materials was not common; however, there are several sites in upland settings in the Sabine River drainage where good quality lithic raw materials were being used by Middle Archaic hunting-gathering groups (see Walters 2006). At Cooper Lake in Archaic contexts, the non-local lithics that are present primarily originated to the north in gravels in the Red River basin (Fields et al. 1997). Mound complexes of late Middle Archaic age in northern Louisiana at this time also suggest the development of more complex hunter-gatherer societies in certain parts of the Trans-Mississippi South (see Saunders 2010; Saunders et al. 1997; Saunders and Allen 1997), although not apparently in East Texas.

\section{Late Archaic period}

Late Archaic sites are widely distributed in East Texas, occurring along the major streams, near springs, on spring-fed branches, upland ridges, and on tributary drainages of all sizes. In fact, the distribution of Late Archaic sites suggests these groups moderately to extensively ranged over and exploited almost every part of the region and its environmental habitats, and in particular, Anderson (1996a) notes major concentrations of Late Archaic sites along Pleistocene and Holocene deposits of the Red and Little Rivers in southwest Arkansas, northwest Louisiana, and East Texas (Figure 6) as well as in the Ouachita Mountains. Aboriginal populations continued a generalized foraging adaptation, combined with apparent population growth. There are only a few well-dated Late Archaic period components known in Northeast Texas, however, but sites dated to this age are much more common than are Middle Archaic or Early Archaic sites or components (see Table 1).

Some Late Archaic occupations in riverine settings contain earthen middens (i.e., the Yarbrough site along the Sabine River), but generally, sites of this age with features contain burned rock deposits and/or concentrations of burned rocks, as well as small pits. These concentrations of burned rocks are likely evidence for the bulk processing of plant foods in hunter-gatherer earth ovens (Black and Thoms 2014; Thoms 2008).

The Late Archaic occupation in Area $\mathrm{C}$ at the Unionville site had a buried anthrosol or occupational surface that had been darkened or stained by cultural activities, while within the anthrosol itself were two clusters of burned rock features (Cliff et al. 1996). Large pits and rock hearths in a very late Late Archaic component at the Herman Ballew site (41RK222) have age ranges of 2440-3180 years B.P. (Rogers et al. 2001). At the Mockingbird site (41TT550) in the Big Cypress Creek drainage, the Late Archaic component (dated from 2530-2600 years B.P.) contained scattered burned rocks and low amounts of stone tools and projectile points, suggesting it was used only as a temporary encampment or "limited use" area. Many other Late Archaic sites or components are known where burned rocks from hearth construction and use were relatively abundant, along with projectile points, bifacial and flake tools, and flake debris. In cases where 


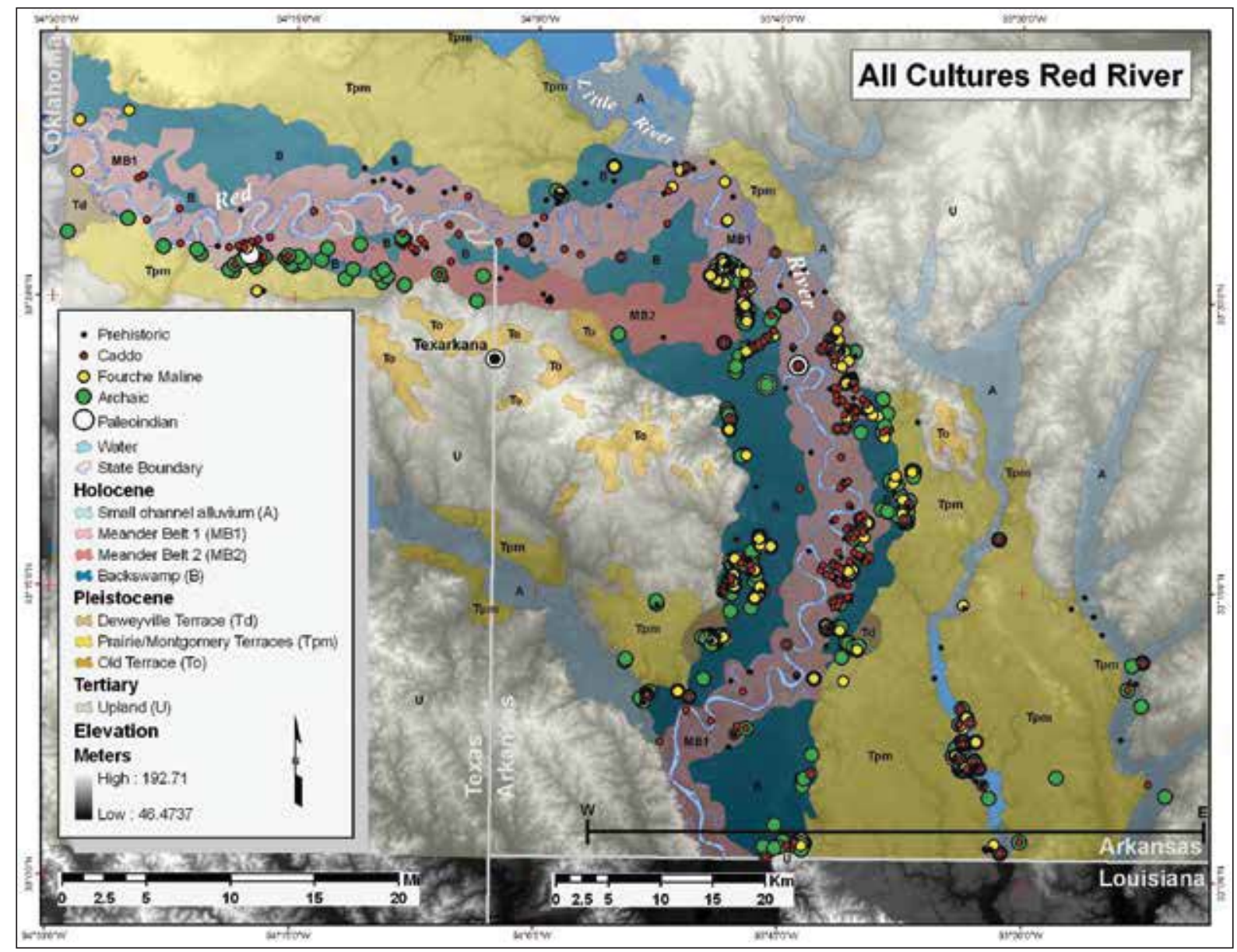

Figure 6. Distribution of prehistoric sites of various ages along the Red River in East Texas and Southwest Arkansas (from Guccione 2008).

there was an extensive use of burned rock features, this does suggest that the cooking and bulk processing of plant foods in ovens and pits was important to some Late Archaic populations in the region.

These settlement data are compatible with higher population densities, limited group mobility but a wide dispersion of camp and foraging areas, the possible establishment of definable territorial ranges, and a welldeveloped foraging economy based on the hunting and gathering of local food resources. No paleobotanical evidence is available that indicates the Late Archaic populations in Northeast Texas cultivated native plant species (i.e., such as sumpweed, sunflower, and chenopod), as was the case by the early first millennium B.C. in many parts of Eastern North America (Smith and Yarnell 2009; Fritz 1990, 1997; Gremillion 2006). Nutshells and prairie turnip (Psoralea sp.) are documented in Late Archaic components at the Unionville site (Cliff et al. 1996) along the lower Sulphur River. The high use of local lithic raw materials during the Late Archaic speaks to a more confined or limited inter-regional interaction at this time (Fields and Tomka 1993; Perttula and Bruseth 1995). By contrast, in the Mississippi River basin of northern Louisiana, Late Archaic sites are marked by extensive quantities of non-local lithic raw materials, particularly novaculite from the Ouachita Mountains and Boone and Pitkin chert (Saunders and Allen 1997:19).

As an example of changes in lithic raw material use, there is a detected change through time (as determined stratigraphically) in the relative proportion of certain lithic raw materials in the lithic debris from the Trammell Crow Pond site (41WD185) on Big Sandy Creek in the Sabine River basin, particularly in the use of local fine-grained to coarse-grained quartzite as well as the use and reduction of non-local lithic raw 
materials (Perttula 2009). In the archeological deposits from $0-80 \mathrm{~cm} \mathrm{bs}$, local lithic raw materials account for 75.1 percent of the lithic debris, dominated by quartzite (66.7 percent of all the lithic debris from those depths, and 89 percent of the local lithic debris). From $80-210 \mathrm{~cm}$ bs, in the Archaic deposits, only 65.3 percent of the lithic debris is from local raw material sources, and the proportion of quartzite among all the local lithic debris is lower, at 69 percent. Other local raw materials are better represented in the older/deeper archaeological deposits, including ferruginous sandstone, petrified wood, and hematite; these three raw materials comprise 28 percent of the locally derived lithic debris. The ferruginous sandstone and hematite flakes are probably the product of the manufacture and shaping of ground stone tools as well as large axes and gouges.

With this shift in the predominance of quartzite is the lesser use of non-local lithic raw materials (24.9 percent) in the younger $(0-80 \mathrm{~cm}$ bs $)$ prehistoric archeological deposits compared to that detected in the $80-210 \mathrm{~cm}$ bs Archaic deposits (34.7 percent). Novaculite, gray chert, and white chert raw materials are the most prevalent non-local materials among the lithic debris throughout the archaeological zones, but each is more abundant in the lowermost and Late Archaic archaeological deposits (see Perttula 2009:Table 3).

The same trends in local vs. non-local lithic raw material use were detected in the lithic debris recovered in archaeological investigations at the Tyler Industries Sand Company site (41UR77) downstream in the Big Sandy Creek valley (Perttula and Ricklis 2005:32-34). There, in archaeological deposits (Zone 3) that appear to date to between 3642-6029 cal years B.P., non-local lithic raw materials were considerably more abundant than they were in the younger (ca. 2719-3442 cal years B.P.) Zone 2 horizon Late Archaic deposits at the site. It appears to be the case that aboriginal populations that utilized the Big Sandy Creek valley prior to ca. 3500 years ago had access to a wider range of non-local lithic raw materials, probably because they were relatively mobile foraging populations that ranged as far north as the middle reaches of the Red River, where they collected high-quality lithic resources during the course of their settlement and foraging forays. After about 3500 years ago, Late Archaic and later Woodland period groups relied much more frequently on locally available lithic raw materials as sources of chipped stone tools. These groups likely had a more territorially-confined settlement/foraging area in the East Texas Pineywoods. Nevertheless, there were contacts between Pineywoods and Red River basin Late Archaic groups that led to the continued acquisition of non-local chipped stone for tool manufacture and use.

The relative frequency of cortical flakes is consistent between the $0-80 \mathrm{~cm}$ and the $80-210 \mathrm{~cm}$ archaeological deposits at the Trammell Crow Pond site, at 14.1 percent and 16.9 percent, respectively. The proportion of cortical flakes among the lithic debris of local lithic raw materials ranges from 17.3-18.3 percent for quartzite (including two core fragments), 33 percent for petrified wood, 36.8 percent for ferruginous sandstone, 60 percent for hematite, 33 percent for red chert (including a core fragment from 80-90 $\mathrm{cm} \mathrm{bs)}$, and 50 percent for light brown/brown chert. A few cortical flakes are also present in the gray chert and novaculite lithic debris from the Late Archaic $(80-210 \mathrm{~cm} \mathrm{bs})$ archaeological deposits. The proportion of cortical flakes in both the $0-80 \mathrm{~cm}$ and $80-210 \mathrm{~cm}$ bs deposits - and the virtual absence of cortical flakes among non-local lithic raw materials - suggests that "stone knappers...were obtaining raw materials at some considerable cost, a factor of either significant distance from material sources, or perhaps some other factor that made access to raw material costly" (Perttula and Ricklis 2005:36). The prevalence of small non-cortical pieces among the lithic debris of non-local lithic raw materials also suggests that completed tools of these high-quality raw materials were brought to the site in Late Archaic times for tool maintenance and resharpening, but not for any substantial on-site tool production efforts. 


\section{SUMMARY AND CONCLUSIONS}

New knowledge concerning the archaeology of the Archaic periods (ca. 10,000-2500 years B.P.) in East Texas is slow in coming. This article has summarized what is currently known about Archaic peoples and groups over this lengthy period of time in the region, including the kinds of sites that have been investigated, their chronological age, and their associated material culture remains.

If preserved, the most informative Archaic period archaeological sites in East Texas are likely to be those that have been buried in the Holocene alluvial deposits found along the major streams in the region. At the present time, however, very few such sites have even been identified in every East Texas river basin, much less been subjected to archaeological investigations. Instead, most Archaic sites in the region are a palimpsest of archaeological material culture remains of varying ages and preservation conditions, thus presenting a considerable analytical challenge to unravel and understand the character of Archaic period sites.

In their consideration of the Archaic period in the Southeastern United States, Anderson and Sassaman (2012:66-111) note the diversity of Archaic period societies in their organizational and structural character, and the effects on them of large-scale environmental and demographic changes: "the tripartite scheme of Early, Middle, and Late Archaic subperiods has long been recognized to coincide with broad climatic trends of the post-glacial era" (Anderson and Sassaman 2012:71). A study of the periods of use of Early to Late Archaic and Woodland period sites in the East Texas Pineywoods and Post Oak Savannah based on the analysis of the kind and proportion of dart points demonstrated that the most intensive use of the region was by Woodland and Late Archaic hunter-gatherers (Perttula and Young 2012). In fact, the intensity of use increased substantially between the Late Archaic and the Woodland period, suggesting that population size (and numbers of sites) continued to increase in the region after 2500 years B.P. The number and types of Early Archaic and Middle Archaic dart points/per century testified to an apparent light use of the landscape during the $8000-10,000$ years B.P. period, as well as from ca. $6500-8000$ years B.P., with more use after 6500 years B.P. by generalist hunter-gatherer foragers. The number of Late Archaic dart points per century increased almost 400 percent over that of the Middle Archaic period as a whole.

In conclusion, these broad trends in the use of the East Texas Pineywoods and Post Oak Savannah by hunter-gatherer groups over a 7500 year period, as tracked by projectile point frequencies and proportions per century in dart point samples, reflect both cultural and demographic changes as well as technological adjustments and adaptations associated with major climatic changes in the region, particularly in temperature and available precipitation, just as they do in other parts of North America (e.g. Collins et al. 2011; Munoz et al. 2010). The development of bulk processing of plant foods is attested to in the archaeological record of Middle and Late Archaic period groups. By the onset of the Late Archaic, changes in the distribution of prairie and forest areas, due to generally wetter conditions after ca. 5000 years B.P. than was the case during the preceding Middle Archaic period, were much as they are in modern times. The known distribution, availability, and predictability of food resources in the region at this time apparently led to a substantial growth in American Indian population sizes, as well as decreasing group ranges, that continued through the Woodland period and into the post-A.D. 800 Caddo periods.

Despite the growth in the population of Late Archaic period groups and communities in East Texas, and continued technological developments, there is no evidence in the region for the construction of earthen mounds and monuments. In Louisiana, by contrast, there are a number of earthen mounds in the lower Mississippi Valley that were constructed between 5650-3700 cal. years B.P. - in the latter part of the Middle Archaic and the early years of the Late Archaic (Saunders 2010). These mound complexes seem to be associated with a "great abundance and diversity of freshwater aquatic habitats" (Anderson and Sassaman 2012:78), and perhaps such habitats were absent in East Texas in Middle and Late Holocene times. Also notably lacking in the Archaic periods archaeological record in East Texas is much evidence of the beliefs and rituals of Archaic peoples living in the region, which stands in contrast to much of the eastern Woodlands (see Claassen 2015:11-49). 


\section{NOTES}

1. Anderson and Smith (2003:277-278) consider the Pelican point to be contemporaneous with the Dalton and San Patrice types of the Late Paleoindian period, as do Morehead and Lafitte (2012:Table 3), with a temporal range of ca. 9450-10450 years B.P., but I have included it in the Early Archaic period. Webb (2000) considered Pelican points to be preforms for var. Hope San Patrice points.

\section{ACKNOWLEDGMENTS}

I want to thank Bill Young, Mark Walters, and Tom Middlebrook for providing information on East Texas Archaic sites and collections; Bill was particularly constructive in getting a firmer grasp on the realities of East Texas dart point typology. Thanks to Ross Fields, Robert Rogers, and Jeff Girard for looking over Tables 1-2; thanks also to Zac Selden for continuing to compile Archaic period radiocarbon dates from East Texas sites. Finally, I am also grateful for Lance Trask for preparing Figures 1, 4, and 5 in this article, and to Sandy Hannum for the preparation of Figure 2.

\section{REFERENCES CITED}

Albert, B. M.

2007 Climate, fire, and land-use history in the oak-pine-hickory forests of Northeast Texas during the past 3500 years. Castanea 72(2):81-90.

2011 Middle to Late Holocene Palynology of Vibra Cores from 41AN38 and Caddo Creek. In Archeological Investigations at the Lang Pasture Site (41AN38) in the Upper Neches River Basin of East Texas, assembled and edited by T. K. Perttula, D. B. Kelley, and R. A. Ricklis, pp. 497-558. Report No. 129. Texas Department of Transportation, Archeological Studies Program, Environmental Affairs Division, Austin.

Albert, L. E.

1981 Ferndale Bog and Natural Lake: Five Thousand Years of Environmental Change in Southeastern Oklahoma. Studies in Oklahoma's Past No. 7. Oklahoma Archeological Survey, Norman.

Anderson, D. G.

1996a Models of Paleoindian and Early Archaic Settlement in the Lower Southeast. In The Paleoindian and Early Archaic Southeast, edited by D. G. Anderson and K. E. Sassaman, pp. 29-57. University of Alabama Press, Tuscaloosa.

1996b Approaches to Modeling Regional Settlement in the Archaic Period Southeast. In The Archaeology of the Mid-Holocene Southeast, edited by K. E. Sassaman and D. G. Anderson, pp. 157-176. University Press of Florida, Gainesville.

Anderson, D. G. and K. E. Sassaman

2012 Recent Developments in Southeastern Archaeology: From Colonization to Complexity. The SAA Press, Society for American Archaeology, Washington, D.C.

Anderson, D. G. and S. D. Smith

2003 Archaeology, History, and Predictive Modeling: Research at Fort Polk, 1972-2002. University of Alabama Press, Tuscaloosa.

Anderson, D. G., M. Russo, and K. E. Sassaman

2007 Mid-Holocene cultural dynamics in southeastern North America. In Climate Change and Cultural Dynamics: A Global Perspective on Mid-Holocene Transitions, edited by D. G. Anderson, K. A. Maasch, and D. H. Sandweiss, pp. 457-489. Elsevier, Amsterdam. 
Bateman, M. D.

2005 Quartz Optical Dating Report at 41UR77. In Archeological Testing at 41 UR77 on Big Sandy Creek, Upshur County, Texas, by T. K. Perttula and R. A. Ricklis, pp. 57-63. Archeological Studies Program, Report No. 71. Texas Department of Transportation, Environmental Affairs Division, Austin.

2011 Quartz Optical Dating of Sediment Samples from 41AN38. In Archeological Investigations at the Lang Pasture Site (41AN38) in the Upper Neches River Basin of East Texas, assembled and edited by T. K. Perttula, D. B. Kelley, and R. A. Ricklis, pp. 559-578. Report No. 129. Texas Department of Transportation, Environmental Affairs Division, Archeological Studies Program, Austin.

Black, S. L. and A. V. Thoms

2014 Hunter-Gatherer Earth Ovens in the Archaeological Record: Fundamental Concepts. American Antiquity 79(2):204-226.

Boulanger, M. T., M. D. Glascock, M. S. Shackley, C. Skinner, and J. J. Thatcher

2014 Likely Source Attribution for a Possible Paleoindian Obsidian Tool from Northwest Louisiana. Louisiana Archaeology 37:81-88.

Boulter, C. H.

2007 Reconstructing the palaeoenvironmental dynamics of East Central Texas since the Last Glacial Maximum. Ph.D. dissertation, Department of Geography, University of Sheffield.

Bousman, C. B.

1998 Paleoenvironmental Change in Central Texas: The Palynological Evidence. Plains Anthropologist 43(164):201-219.

Bousman, C. B. and E. Oksanen

2012 The Protoarchaic in Central Texas and Surrounding Areas. In From the Pleistocene to the Holocene: Human Organization and Cultural Transformations in Prehistoric North America, edited by C. B. Bousman and B. J. Vierra, pp. 197-232. Texas A\&M University Press, College Station.

Bousman, C. B. and S. A. Skinner

2007 The Search for Late Pleistocene pre-Clovis Archeology in Texas: Problems and Potentials. Bulletin of the Texas Archeological Society 78:37-46.

Bousman, C. B., B. W. Baker, and A. C. Kerr

2004 Paleoindian Archeology in Texas. In The Prehistory of Texas, edited by T. K. Perttula, pp. 15-97. Texas A\&M University Press, College Station.

Bousman, C. B., M. B. Collins, P. Goldberg, T. Stafford, J. Guy, B. W. Baker, D. G. Steele, M. Kay, A. Kerr, G. Fredlund, P. Dering, V. Holliday, D. Wilson, W. Gose, S. Dial, P. Takac, R. Balinksy, M. Masson, and J. F. Powell 2002 The Palaeoindian-Archaic transition in North America: new evidence from Texas. Antiquity 76:980-990.

Bradley. R. S., K. R. Briffa, J. Cole, M. K. Hughes, and T. J. Osborn

2003 The Climate of the Last Millennium. In Paleoclimate, Global Change, and the Future, edited by K. D. Alverson, R. S. Bradley, and T. F. Pedersen, pp. 105-141. Springer-Verlag, Berlin.

Brown, D. O.

1998 Late Holocene Climates of North-Central Texas. Plains Anthropologist 43(164):157-172.

Bryson, R. A. and K. M. DeWall

2007 A Paleoclimatology Workbook: High Resolution, Site-Specific, Macrophysical Climate Modeling. Mammoth Site, Hot Springs, South Dakota.

Carpenter, S. and P. Paquin

2010 Towards a Genealogy of Texas Stone Projectile Points. Bulletin of the Texas Archeological Society $81: 153-175$. 
Cheatwood, G.

1988 Notes on the Stratigraphic Position of Archeological Remains in the Sulphur River Valley, Red River County, Texas. In Quaternary Geomorphology at Cooper Basin: A Framework for Archeological Inquiry, Delta and Hopkins Counties, Texas, by C. B. Bousman, M. B. Collins, and T. K. Perttula, pp. 139-143. Reports of Investigations No. 55. Prewitt \& Associates, Inc., Austin.

Claassen, C. L.

2015 Beliefs and Rituals in Archaic Eastern North America. University of Alabama Press, Tuscaloosa.

Cliff, M. B. and T. K. Perttula

2002 Results of National Register Investigations Conducted on Site 41PN175, Panola County, Texas. Archeological Studies Program, Report No. 32, Texas Department of Transportation, and Document No. 010242, PBS\&J, Austin.

Cliff, M. B., M. M. Green, S. M. Hunt, D. Shanabrook, and D. E. Peter

1996 Excavations at 41CS151, Area C, White Oak Creek Mitigation Area (WOCMA), Cass County, Texas. White Oak Creek Mitigation Area Archeological Technical Series, Report of Investigations, Number 4. Geo-Marine, Inc., Plano.

Coleman, R. E.

2009 Environmental History. In Ouachita National Forest: An Archeological Overview, by R. E. Coleman, M. Etchieson, T. K. Perttula, and S. Marceaux, pp. 13-28. Ouachita National Forest, Hot Springs, Arkansas.

Collins, M. B. (assembler and editor)

1998 Wilson-Leonard: An 11,000-year Archeological Record of Hunter-Gatherers in Central Texas, Volume I: Introduction, Background, and Synthesis. Studies in Archeology 31, Texas Archeological Research Laboratory, The University of Texas at Austin, and Archeology Studies Program, Report 10, Texas Department of Transportation, Environmental Affairs Division, Austin.

Collins, M. B., D. M. Yelacic, and C. B. Bousman

2011 "Realms," A Look at Paleoclimate and Projectile Points in Texas. Bulletin of the Texas Archeological Society 82:3-30.

Cranford, D. J., E. L. Dowd, and D. G. Wyckoff (compilers and editors)

2009 Geoarchaeology and the Cross Timbers. Memoir 13. Oklahoma Anthropological Society, Norman.

Crowley, T. J.

2000 Causes of Climate Change Over the Past 1000 Years. Science 289:270-277.

Diggs, G. M., Jr., B. L. Lipscomb, M. D. Reed, and R. J. O'Kennon

2006 Illustrated Flora of East Texas, Volume One. Botanical Research Institute of Texas, Fort Worth.

Dixon, B., L. O'Kelly, D. Sherman, C. Wallace, R. Marie, L. Ellis, and S. Hoskins

2008 National Register of Historic Places Eligibility Testing of Archaic Period Site 41RK468, Rusk County, Texas. Document No. 080011. PBS\&J, Austin.

Duffield, L. F.

1963 The Wolfshead Site: An Archaic-Neo-American Site in San Augustine County, Texas. Bulletin of the Texas Archeological Society 34:83-141.

Emerson, T. E., D. L. McElrath, and A. C. Fortier (editors)

2009 Archaic Societies: Diversity and Complexity across the Midcontinent. State University of New York Press, Albany. 
Ferring, C. R.

1994 McGee Creek in Regional Paleoenvironmental Context. In Past Environments and Prehistory at McGee Creek Reservoir, Atoka County, Oklahoma, edited by C. R. Ferring, pp. 29-43. McGee Creek Archaeological Project Reports, Volume V, Part 4. Institute of Applied Sciences, University of North Texas, Denton.

1995 Middle Holocene Environments, geology, and Archaeology in the Southern Plains. In Archaeological Geology of the Archaic Period in North America, edited by E. A. Bettis, pp. 21-35. Special Paper 297. Geological Society of America, Boulder, Colorado.

Ferring, C. R. and B. C. Yates

1998 Holocene Geoarchaeology and Prehistory of the Ray Roberts Lake Area, North Central Texas. Institute of Applied Sciences, University of North Texas, Denton.

Fields, R. C.

2004 The Archeology of the Post Oak Savanna of East Central Texas. In The Prehistory of Texas, edited by T. K. Perttula, pp. 347-369. Texas A\&M University Press, College Station.

Fields, R. C. and S. A. Tomka

1993 Hunter-Gatherer Mobility in Northeast Texas. In Archeology in the Eastern Planning Region, Texas: A Planning Document, edited by N. A. Kenmotsu and T. K. Perttula, pp. 69-95. Cultural Resource Management Report 3. Department of Antiquities Protection, Texas Historical Commission, Austin.

Fields, R. C., M. E. Blake, and K. W. Kibler

1997 Synthesis of the Prehistoric and Historic Archeology of Cooper Lake, Delta and Hopkins Counties, Texas. Reports of Investigations No. 104. Prewitt \& Associates, Inc., Austin.

Frederick, C. D., M. D. Bateman, and R. Rogers

2002 Evidence for eolian deposition in the sandy uplands of East Texas and the implications for archaeological site integrity. Geoarchaeology 17(2):191-217.

Fritz, G. J.

1990 Multiple Pathways to Farming in Precontact Eastern North America. Journal of World Prehistory $4: 387-435$.

1997 A Three-Thousand-Year-Old Seed Crop from Marble Bluff, Arkansas. In People, Plants, and Landscape: Studies in Paleoethnobotany, edited by K. J. Gremillion, pp. 42-62. University of Alabama Press, Tuscaloosa.

Furman, E. and C. Amick

2005 Archaeological Investigations at 41AN115. Journal of Northeast Texas Archaeology 21:15-63.

Gadus, E. F., R. C. Fields, C. B. Bousman, S. A. Tomka, and M. A. Howard

2002 Excavations at the Finley Fan Site (41HP159), Cooper Lake Project, Hopkins County, Texas. Reports of Investigations No. 78. Prewitt \& Associates, Inc., Austin.

Gadus, E. F., R. C. Fields, J. K. McWilliams, J. Dockall, and M. C. Wilder

2006 National Register Testing of Seven Prehistoric Sites in the Sabine Mine's Area Q, Harrison County, Texas. Reports of Investigations No. 147. Prewitt \& Associates, Inc., Austin.

Girard. J. S.

2000 Regional Archeology Program Management Unit 1, Eleventh Annual Report. Northwestern State University of Louisiana, Natchitoches.

Girard, J. S., N. Heller, J. P. Dering, S. L. Scott, H. E. Jackson, and G. L. Stringer

2011 Investigations at the Conly Site, a Middle Archaic Period Settlement in Northwest Louisiana. Louisiana Archaeology 32:5-77. 
Gremillion, K. J.

2006 Southeast Plants. In Environment, Origins, and Population, edited by D. Stafford, B. D. Smith, D. H. Ubelaker, and E. J. E. Szathmary, pp. 388-395. Handbook of the North American Indians, Volume 3. Smithsonian Institution, Washington, D.C.

Guccione, M. J.

2008 Impact of the alluvial style on the geoarcheology of stream valleys. Geomorphology 101:378-401.

Holloway, R. G.

1994 Ferndale Bog: A Record of Late Pleistocene-Holocene Climate and Vegetational Change. In Past Environments and Prehistory at McGee Creek Reservoir, Atoka County, Oklahoma, edited by C. R. Ferring, pp. 9-27. McGee Creek Archaeological Project Reports, Volume V, Part 4. Institute of Applied Sciences, University of North Texas, Denton.

Jackson, H. E. and S. L. Scott

2001 Archaic Faunal Utilization in the Louisiana Bottomlands. Southeastern Archaeology 20(2):187-196.

Jennings, T. A.

2008a San Patrice Technology and Mobility across the Plains-Woodland Border. Memoir 12, Oklahoma Anthropological Society, and R. E. Bell Monographs in Anthropology No. 5, Sam Noble Oklahoma Museum of Natural History, University of Oklahoma, Norman.

2008b San Patrice: An Example of Late Paleoindian Adaptive Versatility in South-Central North America. American Antiquity 73(3):539-559.

Johnson, L., Jr.

1962 The Yarbrough and Miller Sites of Northeastern Texas, With a Preliminary Definition of the La Harpe Aspect. Bulletin of the Texas Archeological Society 32:141-284.

1989 Great Plains Interlopers in the Eastern Woodlands during Paleo-Indian Times. Report 36. Office of the State Archeologist, Texas Historical Commission, Austin.

Jones, B. C.

1957 The Grace Creek Sites, Gregg County, Texas. Bulletin of the Texas Archeological Society 28:198-231.

Jones, J. L. and T. Middlebrook

1995 Test Excavations at an Archaic Site in San Augustine County, Texas. Paper presented at the 1995 East Texas Archeological Conference, Tyler.

Jordan, T. G.

1981 Trails to Texas: Southern Routes of Western Cattle Ranching. University of Nebraska Press, Lincoln.

Keller, J. E.

1998 Archaeological Investigations at 41 HS559 and 41HS606, Harrison County, Texas. Report of Investigations 3-2000. Southern Archaeological Consultants, Inc., Harlingen.

Kidder, T. R. and K. E. Sassaman

2009 The View from the Southeast. In Archaic Societies: Diversity and Complexity across the Midcontinent, edited by T. E. Emerson, D. L. McElrath, and A. C. Fortier, pp. 667-694. State University of New York Press, Albany.

Koldehoff, B. and J. A. Walthall

2009 Dalton and the Early Holocene Midcontinent: Setting the Stage. In Archaic Societies: Diversity and Complexity across the Midcontinent, edited by T. E. Emerson, D. L. McElrath, and A. C. Fortier, pp. 137-151. State University of New York Press, Albany. 
Lipo, C. P., M. J. O'Brien, M. Collard, and S. J. Shennan (editors)

2006 Mapping Our Ancestors: Phylogenetic Approaches in Anthropology and Prehistory. AldineTransaction, New Brunswick, New Jersey.

Lohse, J. C.

2005 National Register Eligibility Testing of the Weaver Creek Site, 41BW692, Bowie County, Texas. Archeological Studies Program, Report No. 69. Texas Department of Transportation. Environmental Affairs Division, Austin.

Lopinot, N. H., J. H. Ray, and M. D. Conner (editors)

2005 Regional Research and the Archaic Record at the Big Eddy Site (23CE426), Southwest Missouri. Special Publication No. 4. Center for Archaeological Research, Southwest Missouri State University, Springfield.

McElrath, D. L., A. C. Fortier, and T. E. Emerson

2009 An Introduction to the Archaic: Societies of the Midcontinent. In Archaic Societies: Diversity and Complexity across the Midcontinent, edited by T. E. Emerson, D. L. McElrath, and A. C. Fortier, pp. 3-21. State University of New York Press, Albany.

Moore, C. R. and V. G. Dekle

2010 Early horticultural economies in eastern North America. World Archaeology 42(4):595-608.

Morehead, J. and B. Lafitte

2012 The San Patrice Culture at Fort Polk, Louisiana: The Anacoco Phase and the Distribution of Related Paleoindian and Early Archaic Cultural Components. Louisiana Archaeology 37:9-80.

Morse, D. F.

1997 Sloan: A Paleoindian Dalton Cemetery in Arkansas. Smithsonian Institution Press, Washington, D.C.

Munoz, S. E., K. Gajewski, and M. C. Peros

2010 Synchronous environmental and cultural change in the prehistory of the northeastern United States. Science 107(51):22008-22013.

O’Brien, M. J. and R. L. Lyman

2003 Cladistics and Archaeology. University of Utah Press, Salt Lake City.

Perttula, T. K.

1984 Patterns of Prehistoric Lithic Raw Material utilization in the Caddoan Area: The Western Gulf Coastal Plain. In Prehistoric Chert Exploitation Studies from the Midcontinent, edited by B. M. Butler and E. E. May, pp. 129-148. Occasional Paper 2. Center for Archaeological Investigations, Southern Illinois University-Carbondale.

1989 The Paleoindian Archaeological Record in Northeast Texas: Evidence from Avocational Collecting. Current Research in the Pleistocene 6:19-21.

1997 A Compendium of Radiocarbon and Oxidizable Carbon Ratio Dates from Archaeological Sites in East Texas, with a Discussion of the Age and Dating of Select Components and Phases. Radiocarbon 39(3):305-341.

1999 (editor) The Hurricane Hill Site (41HP106): The Archaeology of a Late Archaic/Early Ceramic and Early-Middle Caddoan Settlement in Northeast Texas. 2 Vols. Special Publication No. 4. Friends of Northeast Texas Archaeology, Pittsburg and Austin.

2002a An Early Radiocarbon Date from a Prehistoric Site in Anderson County, Texas. Journal of Northeast Texas Archaeology 16:43-44.

2002b (editor) Archeological Investigations at Proposed Lake Naconiche, Nacogdoches County, Texas. Report of Investigations No. 42. 2 Vols. Archeological and Environmental Consultants, Austin.

2004 The Prehistoric and Caddoan Archeology of the Northeastern Texas Pineywoods. In The Prehistory of Texas, edited by T. K. Perttula, pp. 370-407. Texas A\&M University Press, College Station. 
2005 Interim Report: National Register Eligibility Testing of 41CP220 along Kitchen Branch, Camp County, Texas. Coastal Environments, Inc., Baton Rouge.

2008 (editor) Lake Naconiche Archeology, Nacogdoches County, Texas: Results of the Data Recovery Excavations at Five Prehistoric Archeological Sites. 2 Vols. Report of Investigations No. 60. Archeological \& Environmental Consultants, LLC, Austin.

2009 The Archeology of a Sandy Mantle Site in East Texas: 1987 Excavations at the Trammell Crow Pond Site (41WD185) in the Big Sandy Creek Valley. The Record 56(1):58-78. Dallas Archaeological Society, Dallas, Texas.

2013 Paleoindian to Middle Archaic Projectile Points from East Texas. Journal of Northeast Texas Archaeology 42:33-46.

Perttula, T. K. and J. E. Bruseth

1995 Trade and Exchange in Eastern Texas, 1100 B.C.-A.D. 800. In "Exchange in the Lower Mississippi Valley and Contiguous Areas in 1100 B.C.," edited by J. L. Gibson. Louisiana Archaeology 17:93-121.

Perttula, T. K. and B. Nelson

2006 Archeological Investigations at the Polk Estates Site (41CP245), Camp County, Texas. Journal of Northeast Texas Archaeology 24:1-83.

2009 Prehistoric Artifact Assemblages from Sites along Hickory Creek in the Davy Crockett National Forest, Houston County, Texas. Special Publication No. 14. Friends of Northeast Texas Archaeology and Archeological \& Environmental Consultants, LLC, Austin and Pittsburg.

Perttula, T. K. and R. A. Ricklis

2005 Archeological Testing at 41 UR77 on Big Sandy Creek, Upshur County, Texas. Archeological Studies Program, Report No. 71. Texas Department of Transportation, Environmental Affairs Division, Austin.

Perttula, T. K., B. D. Skiles, M. B. Collins, M. C. Trachte, and F. Valdez, Jr.

1986 "This Everlasting Sand Bed": Cultural Resources Investigations at the Texas Big Sandy Project, Wood and Upshur Counties, Texas. Reports of Investigations No. 52. Prewitt and Associates, Inc., Austin.

Perttula, T. K. and W. L. Young

2012 Trends in Archaic and Woodland Period Use of the Middle Sabine River Basin Based on Dart Point Proportions. Journal of Northeast Texas Archaeology 37:23-30.

Pevny, C. D.

2014 Twin Bird Islands (16CD118): A Late Paleoindian-Early Archaic Site in Caddo Parish, Louisiana. Louisiana Archaeology 37:108-141.

Ray, J. H. and N. H. Lopinot

2003 Middle Archaic Components and Chert Use at the Bass Site. Missouri Archaeological Society Quarterly 20(2):4-16.

Ray, J. H., N. H. Lopinot, and E. R. Hajic

2009 Archaic Prehistory of the Western Ozarks of Southwest Missouri. In Archaic Societies: Diversity and Complexity across the Midcontinent, edited by T. E. Emerson, D. L. McElrath, and A. C. Fortier, pp. 155-197. State University of New York Press, Albany.

Rees, M. A.

2010 Paleoindian and Early Archaic. In Archaeology of Louisiana, edited by M. A. Rees, pp. 34-62. Louisiana State University Press, Baton Rouge. 
Reimer, P. J., M. G. L. Baillie, E. Bard, A. Bayliss, J. W. Beck, P. G. Blackwell, C. Bronk Ramsey, C. E. Buck, G. S. Burr, R. L. Edwards, M. Friedrich, P. M. Grootes, T. P. Guilderson, I. Hajdas, T. J. Heaton, A. G. Hogg, K. A. Hughen, B. Kromer, F. G. McCormac, S. W. Manning, R. W. Reimer, D. A. Richards, J. R. Southon, S. Talamo, C. S. M. Turney, J. van der Plicht, and C. E. Weyhenmeyer

2009 IntCal09 and Marine09 Radiocarbon Age Calibration Curves, 0-50,000 cal BP. Radiocarbon 51:11111150 .

Rogers, R. and T. K. Perttula

2004 The Oak Hill Village Site (41RK214), Rusk County, Texas. Document No. 030083. PBS\&J, Austin.

Rogers, R., M. A. Nash, and T. K. Perttula

2001 Excavations at the Herman Ballew Site (41RK222), Rusk County, Texas. Document No. 000021. PBS\&J, Austin.

Sassaman, K. E.

2008 The New Archaic: It Ain't What It Used to Be. The SAA Archaeological Record 8(5):6-8.

Saunders, J.

2010 Middle Archaic and Watson Brake. In Archaeology of Louisiana, edited by M. A. Rees, pp. 63-77. Louisiana State University Press, Baton Rouge.

Saunders, J. and T. Allen

1997 The Archaic Period. Louisiana Archaeology 22:1-30.

Saunders, J. W., R. D. Mandel, R. T. Saucier, E. T. Allen, C. T. Hallmark, J. K. Johnson, E. H. Jackson, C. M. Allen, G. L. Stringer, D. S. Frink, J. K. Feathers, S. Williams, K. J. Gremillion, M. F. Vidrine, and R. Jones

1997 A Mound Complex in Louisiana at 5400-5000 Years Before the Present. Science 277:1796-1799.

Schambach, F. F.

1998 Pre-Caddoan Cultures in the Trans-Mississippi South: A Beginning Sequence. Research Series 53. Arkansas Archeological Survey, Fayetteville.

Selden, R. Z., Jr.

2013 A Preliminary Temporal Analysis of the East Texas Archaic. Journal of Northeast Texas Archaeology 42:55-69.

Selden, R. Z., Jr. and T. K. Perttula

2013a Radiocarbon Trends and the East Texas Caddo Tradition (ca. A.D. 800-1680). Southeastern Archaeology 32(1):85-96.

2013b Temporal Dynamics of East Texas Caddo Sites with 10 or More Radiocarbon Dates. Journal of Northeast Texas Archaeology 41:81-99.

Shott, M.

2015 Theory in Archaeology: Morphometric Approaches to the Study of Fluted Points. In Lithic Technological Systems and Evolutionary Theory, edited by N. Goodale and W. Andrefsky, Jr., pp. 48-60. Cambridge University Press, New York.

Skinner, S. A., C. B. Bousman, N. Plumb, A. P. Wilson, J. Todd, and T. Jennings

2005 Archaeology and Quaternary Geology of Lake Ralph Hall, Fannin County, Texas. Cultural Resources Report 2005-31. AR Consultants, Inc., Dallas.

Slaughter, B. H. and B. R. Hoover

1965 An Antler Artifact from the Late Pleistocene of Northeastern Texas. American Antiquity 30:351-352.

Smith, B. D. and R. A. Yarnell

2009 Initial formation of an indigenous crop complex in eastern North America at 3800 B.P. Proceedings of the National Academy of Sciences 106(16):6561-6566. 
Stahle, D. W. and M. K. Cleaveland

1994 Tree-Ring Reconstructed Rainfall over the Southeastern U.S.A. during the Medieval Warm period and Little Ice Age. Climatic Change 26:194-212.

1995 Texas Paleoclimatic Data from Daily to Millenial Time Scales. In The Changing Climate of Texas: Predictability and Implications for the Future, edited by J. Norwine, J. R. Giardino, G. R. North, and J. B. Valdes, pp. 49-69. GeoBooks, College of Geosciences and Maritime Studies, Texas A\&M University, College Station.

Story, D. A.

1990 Cultural History of the Native Americans. In The Archeology and Bioarcheology of the Gulf Coastal Plain, by D. A. Story, J. A. Guy, B. A. Burnett, M. D. Freeman, J. C. Rose, D. G. Steele, B. W. Olive, and K. J. Reinhard, pp. 163-366. 2 Vols. Research Series No. 38. Arkansas Archeological Survey, Fayetteville.

Suhm, D. A. and E. B. Jelks (editors)

1962 Handbook of Texas Archeology: Type Descriptions. Special Publication No. 1, Texas Archeological Society, and Bulletin No. 4, Texas Memorial Museum, Austin.

Thoms, A. V.

2008 The fire stones carry: Ethnographic records and archaeological expectations for hot-rock cookery in western North America. Journal of Anthropological Archaeology 27(4):443-460.

Thurmond, J. P.

1990 Archeology of the Cypress Creek Drainage Basin, Northeastern Texas and Northwestern Louisiana. Studies in Archeology 5. Texas Archeological Research Laboratory, The University of Texas at Austin.

Trubitt, M. B.

2009 Investigating Middle Archaic at the Jones Mill Site. The Arkansas Archeologist 48:71-84.

Tucker, G. C., Jr.

1995 Archaic Lifeways in the Northern Part of the West Gulf Coastal Plain: Results of Excavations at Site 41BW422, Bowie County, Texas. Powers Elevation Company, Inc., Aurora, Colorado.

Turner, E. S. and T. R. Hester

1999 A Field Guide to Stone Artifacts of Texas Indians. Gulf Publishing/Rowman \& Littlefield Publishers, Inc., Lanham, Maryland.

Turner, R. L., Jr.

2006 Hematite Axes of Northeast Texas. Bulletin of the Texas Archeological Society 77:1-31.

Viau, A. E., K. Gajewski, P. Fines, D. E. Atkinson, and M. C. Sawada

2002 Widespread Evidence of 1500 yr Climatic Variability in North America during the Past 14,000 yr. Geology 30:455-458.

Walters, $\mathrm{M}$.

2006 Walters Farm, Smith County, Texas. Journal of Northeast Texas Archaeology 25:40-56.

Webb, C. H.

2000 Stone Points and Tools of Northwestern Louisiana. 2nd Edition. Special Publication No. 1. Louisiana Archaeological Society, Baton Rouge.

Webb, C. H., J. L. Shiner, and E. W. Roberts

1971 The John Pearce Site (16CD56): A San Patrice Site in Caddo Parish, Louisiana. Bulletin of the Texas Archeological Society 42:1-49. 
Wyckoff, D. G. and R. Bartlett

1995 Living on the Edge: Late Pleistocene-Early Holocene Cultural Interaction along the Southeastern Woodlands-Plains Border. In Native American Interactions: Multiscalar Analyses and Interpretations in the Eastern Woodlands, edited by M. S. Nassaney and K. S. Sassaman, pp. 27-72. University of Tennessee Press, Knoxville.

Wyckoff, D. G., E. Dowd, and D. J. Cranford

2009 Summary Perspective of Soils and Prehistory along Oklahoma's Cross Timbers. In Geoarchaeology and the Cross Timbers, compiled and edited by D. J. Cranford, E. L. Dowd, and D. G. Wyckoff, pp. 75-104. Memoir 13. Oklahoma Anthropological Society, Norman. 